\title{
Nitrous oxide emissions from biofilm processes for wastewater treatment
}

\author{
Sabba, Fabrizio; Terada, Akihiko; Wells, George; Smets, Barth F.; Nerenberg, Robert
}

Published in:

Applied Microbiology and Biotechnology

Link to article, DOI:

10.1007/s00253-018-9332-7

Publication date:

2018

Document Version

Peer reviewed version

Link back to DTU Orbit

Citation $(A P A)$ :

Sabba, F., Terada, A., Wells, G., Smets, B. F., \& Nerenberg, R. (2018). Nitrous oxide emissions from biofilm processes for wastewater treatment. Applied Microbiology and Biotechnology, 102(22), 9815-9829.

https://doi.org/10.1007/s00253-018-9332-7

\section{General rights}

Copyright and moral rights for the publications made accessible in the public portal are retained by the authors and/or other copyright owners and it is a condition of accessing publications that users recognise and abide by the legal requirements associated with these rights.

- Users may download and print one copy of any publication from the public portal for the purpose of private study or research.

- You may not further distribute the material or use it for any profit-making activity or commercial gain

- You may freely distribute the URL identifying the publication in the public portal 


\section{Nitrous Oxide Emissions from Biofilm Processes for Wastewater}

2 Treatment

3 F. Sabba, A. Terada, G. Wells, B.F. Smets, R. Nerenberg*

4

5 Fabrizio Sabba

6 Department of Civil and Environmental Engineering

7 Northwestern University

82145 Sheridan Road,

9 Evanston, IL 60208, USA

10 ORCID: 0000-0002-6369-9432

12 Akihiko Terada

13 Department of Chemical Engineering and Institute of Global Innovation Research

14 Tokyo University of Agriculture and Technology,

15 Naka 2-24-16, Koganei, Tokyo, 184-8588, Japan

16 ORCID: 0000-0002-9258-6912

George Wells

20 Northwestern University

212145 Sheridan Road,

22 Evanston, IL 60208, USA

23 ORCID: 0000-0002-9100-1628

\section{Barth F. Smets}

27 Technical University of Denmark,

28 Miljøvej Building 113,

292800 Kongens Lyngby, Denmark

30 ORCID: 0000-0003-4119-6292

31

Robert Nerenberg

33 Department of Civil and Environmental Engineering and Earth Sciences

34 University of Notre Dame

35156 Fitzpatrick Hall

36 Notre Dame, IN 46556, USA

37 ORCID: 0000-0003-2203-5004

38 *Corresponding author

39 Nerenberg.1@nd.edu

$40 \quad 574-631-4098$ 


\section{Abstract}

43 This paper discusses the microbial basis and the latest research on nitrous oxide $\left(\mathrm{N}_{2} \mathrm{O}\right)$ emissions

44 from biofilms processes for wastewater treatment. Conditions that generally promote $\mathrm{N}_{2} \mathrm{O}$

45 formation in biofilms include (1) low DO values, or spatial DO transitions from high to low within

46 the biofilm; (2) DO fluctuations within biofilm due to varying bulk DO concentrations or varying

47 substrate concentrations; (3) conditions with high reaction rates, which lead to greater formation

48 of intermediates, e.g., hydroxylamine $\left(\mathrm{NH}_{2} \mathrm{OH}\right)$ and nitrite $\left(\mathrm{NO}_{2}{ }^{-}\right)$, that promote $\mathrm{N}_{2} \mathrm{O}$ formation;

49 and (4) electron donor limitation for denitrification. Formation of $\mathrm{N}_{2} \mathrm{O}$ directly results from the

50 activities of ammonia-oxidizing bacteria (AOB), ammonia-oxidizing archaea (AOA), and

51 heterotrophic denitrifying bacteria. More research is needed on the roles of AOA, comammox, and

52 specialized denitrifying microorganisms. In nitrifying biofilms, higher bulk ammonia $\left(\mathrm{NH}_{3}\right)$

53 concentrations, higher nitrite $\left(\mathrm{NO}_{2}{ }^{-}\right)$concentrations, lower dissolved oxygen (DO), and greater

54 biofilm thicknesses result in higher $\mathrm{N}_{2} \mathrm{O}$ emissions. In denitrifying biofilms, $\mathrm{N}_{2} \mathrm{O}$ accumulates at

55 low levels as an intermediate, and at higher levels at the oxic/anoxic transition regions of the

56 biofilms and where COD becomes limiting. $\mathrm{N}_{2} \mathrm{O}$ formed in the outer regions can be consumed in

57 the inner regions if COD penetrates sufficiently. In membrane-aerated biofilms, where

58 nitrification takes place in the inner, aerobic biofilm region, the exterior anoxic biofilm can serve

59 as a $\mathrm{N}_{2} \mathrm{O}$ sink. Reactors that include variable aeration or air scouring, such as denitrifying filters,

60 trickling filters, or rotating biological contactors (RBCs), can form peaks of $\mathrm{N}_{2} \mathrm{O}$ emissions during

61 or following a scouring or aeration event. $\mathrm{N}_{2} \mathrm{O}$ emissions from biofilm processes depend on the

62 microbial composition, biofilm thickness, substrate concentrations and variability, and reactor type

63 and operation. Given the complexity and difficulty in quantifying many of these factors, it may

64 be difficult to accurately predict emissions for full-scale treatment plants. However, a better

65 understanding of the mechanisms, and the impacts of process configurations, can help minimize

$66 \mathrm{~N}_{2} \mathrm{O}$ emission from biofilm processes for wastewater treatment.

67

68 Keywords: $\mathrm{N}_{2} \mathrm{O}$, biofilms, hydroxylamine, MBBR, MABR, MBfR, granules

69

70

71

72 
75 Wastewater treatment processes can be a significant source of nitrous oxide $\left(\mathrm{N}_{2} \mathrm{O}\right)$, a powerful 76 greenhouse gas (GHG) with a global warming potential around 300 times that of carbon dioxide $77 \quad\left(\mathrm{CO}_{2}\right)$ (Montzka et al. 2011). $\mathrm{N}_{2} \mathrm{O}$ is very stable, and may persist in the atmosphere for over 120 78 years (Kampschreur et al. 2009; Schreiber et al. 2012). The U.S. Environmental Protection 79 Agency (EPA) estimates that U.S. wastewater treatment plants emit around $5.2 \mathrm{Tg} \mathrm{N}_{2} \mathrm{O} \mathrm{yr}^{-1}$ as $80 \mathrm{CO}_{2}$ equivalents (Ritter 2014), and these amounts are expected to increase with time (Law et al. 81 2012; Okabe et al. 2011).

82 Much past research has addressed $\mathrm{N}_{2} \mathrm{O}$ emissions from suspended growth processes (Ahn 83 et al. 2010; Kampschreur et al. 2009; Law et al. 2012). However, much less is known about 84 emissions from biofilm processes, such as the moving bed biofilm reactor (MBBR), integrated 85 fixed-film activated sludge (IFAS), biological aerated filter (BAF), granular sludge, and 86 membrane-aerated biofilm reactors (MABRs) (Henze et al. 2008; Martin and Nerenberg 2012; 87 Syron and Casey 2008). Biofilm processes are becoming increasingly popular due to their higher volumetric treatment rates, reduced operational costs, minimal need for settling, and operational simplicity (Henze et al. 2008; Khan et al. 2013; Nicolella et al. 2000; WEF 2010).

While the microbial basis of $\mathrm{N}_{2} \mathrm{O}$ formation, i.e., the microorganisms and metabolic pathways leading to its formation, are the same for suspended-growth and biofilm systems, the observed behavior may be very different. This results from the microbial stratification, microbial

93 interactions, substrate gradients, and substrate interactions unique to biofilms, as well as the 94 biofilm reactor configuration (Henze et al. 2008; Law et al. 2012; Vlaeminck et al. 2010a). Thus, 95 the "mechanisms" leading to $\mathrm{N}_{2} \mathrm{O}$ emissions in biofilms may significantly differ from those of 96 suspended growth systems.

Todt and Dorsch (2016) provided a comprehensive review of $\mathrm{N}_{2} \mathrm{O}$ emissions from biofilm 98 99 100 systems. They explored the biochemistry of $\mathrm{N}_{2} \mathrm{O}$ production/consumption in relevant organisms, discussed current biofilm models, evaluated possible environmental factors affecting $\mathrm{N}_{2} \mathrm{O}$ emissions, and tabulated emission factors for different processes. Massara et. al (2017) briefly 101 addressed biofilms as part of a comprehensive review of $\mathrm{N}_{2} \mathrm{O}$ emissions from wastewater 102 processes. This review provides an update, considering new information on the $\mathrm{N}_{2} \mathrm{O}$ emissions 
103 from microbial systems. It also discusses new types of microbial metabolism and different biofilm 104 reactor configurations, and their impacts on $\mathrm{N}_{2} \mathrm{O}$ emissions.

Biofilms are aggregates of microbial cells embedded in a network of self-produced extracellular polymeric substances (EPS) (Flemming et al. 2016; Stoodley et al. 2002). Biofilms are widespread 110 in natural systems (Donlan 2002), and increasingly used in engineered treatment processes, 111 especially for those with low substrate concentrations and high flows (Henze et al. 2008; 112 Nicolella et al. 2000; WEF 2010). Unlike with suspended bacteria, diffusion and reaction in 113 biofilms lead to substrate gradients. As a result, concentrations in the biofilm may differ 114 significantly from those in the bulk liquid (Fig. 1). In addition, bacteria stratify into layers, 115 where different types of metabolism may predominate at different depths within the biofilm.

FIGURE 1

The dynamics of growth, decay, and detachment influence the microbial community structure of biofilms (Elenter et al. 2007). Slow growing organisms may be "pushed out" of the biofilm by faster growing organisms (Lackner et al. 2008; Xavier et al. 2005). Metabolic products

122 may diffuse out of the biofilm or may be consumed by other populations. $\mathrm{pH}$ gradients may form 123 due to proton-producing or consuming processes within the biofilm (Vroom et al. 1999). The 124 greater complexity of biofilms, compared to suspended growth processes, makes their behavior 125 more difficult to predict.

\section{$\mathrm{N}_{2} \mathrm{O}$ AND NITROGEN CYCLE}

129 This section discusses basic microbial transformations that affect $\mathrm{N}_{2} \mathrm{O}$ formation in wastewater 130 treatment processes. These processes are relevant to both suspended growth and biofilm processes. 131 The relationship between these transformations and $\mathrm{N}_{2} \mathrm{O}$ formation in biofilms is discussed in 132 subsequent sections. 
The nitrogen cycle includes a number of $\mathrm{N}$ species and both microbial and abiotic

134 transformations, where $\mathrm{N}$ varies in redox state between -3 and +5 . While most of the nitrogen cycle is well established, new biotic and abiotic transformation processes continue to be discovered (Daims et al. 2016; Kuypers et al. 2018; Schreiber et al. 2012; Stein and Klotz 2016). Figure 2 schematically shows key $\mathrm{N}$ species and biological transformations. For wastewater treatment processes, the key transformations include nitrification and denitrification, where nitrate $\left(\mathrm{NO}_{3}{ }^{-}\right)$is sequentially reduced to nitrogen gas $\left(\mathrm{N}_{2}\right)$. Both processes can lead to $\mathrm{N}_{2} \mathrm{O}$ formation.

\section{FIGURE 2}

\section{$\mathrm{N}_{2} \mathrm{O}$ from Microorganisms Related to Nitrification}

Nitrification is carried out by the sequential activity of ammonia-oxidizing bacteria (AOB) and archaea (AOA), and nitrite-oxidizing bacteria (NOB). AOB and AOA oxidize ammonia $\left(\mathrm{NH}_{3}\right)$ to nitrite $\left(\mathrm{NO}_{2}{ }^{-}\right.$), with hydroxylamine $\left(\mathrm{NH}_{2} \mathrm{OH}\right)$ as an intermediate (Fig. 3) (Daims et al. 2016; Guo et al. 2017), while $\mathrm{NOB}$ oxidize $\mathrm{NO}_{2}{ }^{-}$to $\mathrm{NO}_{3}{ }^{-}$. AOB directly produce $\mathrm{N}_{2} \mathrm{O}$ through two main pathways: nitrifier denitrification and $\mathrm{NH}_{2} \mathrm{OH}$ oxidation (Fig. 3). NOB, AOA, anammox, and comammox microorganisms may play an indirect role in $\mathrm{N}_{2} \mathrm{O}$ formation by affecting the availability of $\mathrm{NH}_{3}$ and $\mathrm{NO}_{2}$.

\section{FIGURE 3}

In the nitrifier denitrification pathway, AOB reduce $\mathrm{NO}_{2}{ }^{-}$to nitric oxide (NO) and $\mathrm{N}_{2} \mathrm{O}$ (Chandran et al. 2011; Kampschreur et al. 2007; Kim et al. 2010; Tallec et al. 2006) (Fig. 3). The $\mathrm{NH}_{2} \mathrm{OH}$ oxidation pathway involves the oxidation of $\mathrm{NH}_{2} \mathrm{OH}$ to $\mathrm{NO}$ by hydroxylamine oxidoreductase (HAO) and subsequent reduction to $\mathrm{N}_{2} \mathrm{O}$ catalyzed by the enzyme NO reductase (Chandran et al. 2011; Law et al. 2012; Stein 2011) (Fig. 3).

Recent findings show that, in the canonical nitrifying bacteria $N$. europaea, two other routes for $\mathrm{N}_{2} \mathrm{O}$ production exist under anaerobic conditions. One is the direct oxidation of $\mathrm{NH}_{2} \mathrm{OH}$ to $\mathrm{N}_{2} \mathrm{O}$ by cytochrome P460 (Caranto et al. 2016) and the nitrification intermediate NO (Caranto and Lancaster 2017). Although not all AOB share the same route for $\mathrm{N}_{2} \mathrm{O}$ production, these recent 
findings expand on previous knowledge where chemical reactions were thought to be mainly 165 important at higher oxygen $\left(\mathrm{O}_{2}\right)$ levels (Liu et al. 2017a).

$\mathrm{N}_{2} \mathrm{O}$ can also be produced biologically or abiotically by coupling $\mathrm{NH}_{2} \mathrm{OH}$ oxidation with the reduction of $\mathrm{NO}_{2}^{-}$(Harper et al. 2015; Terada et al. 2017), free nitrous acid $\left(\mathrm{HNO}_{2}\right)($ SolerJofra et al. 2016), or NO (Spott et al. 2011). These are termed N-nitrosation hybrid reactions, or simply “hybrid” reactions (Spott and Stange 2011). In addition, metals such as copper (Harper et al. 2015) and manganese (Heil et al. 2015) can catalyze abiotic $\mathrm{N}_{2} \mathrm{O}$ production from $\mathrm{NH}_{2} \mathrm{OH}$ via the hybrid reaction. Under some conditions, the hybrid reaction can become a predominant pathway for $\mathrm{N}_{2} \mathrm{O}$ production in a partial nitrifying reactor (Soler-Jofra et al. 2018; Terada et al. 2017). $\mathrm{N}_{2} \mathrm{O}$ production via the hybrid reaction is enhanced in the presence of AOB (Liu et al. 2017a; Terada et al. 2017).

Under aerobic conditions, $\mathrm{N}_{2} \mathrm{O}$ is mainly formed via the $\mathrm{NH}_{2} \mathrm{OH}$ pathway, and rates are relatively low. When DO concentrations decrease, the nitrifier denitrification pathway becomes more important, leading to higher rates of $\mathrm{N}_{2} \mathrm{O}$ formation (Chung and Chung 2000; Kampschreur et al. 2009; Ma et al. 2017a; Park et al. 2000; Tallec et al. 2008). However, under complete anoxic conditions $\mathrm{N}_{2} \mathrm{O}$ emissions are again low due to the lack of $\mathrm{DO}$ for $\mathrm{NH}_{3}$ oxidation (Fig. 3). Spikes of $\mathrm{N}_{2} \mathrm{O}$ production can occur at transitions from anoxic to aerobic, or aerobic to anoxic, conditions, due to an electron imbalance (Domingo-Felez et al. 2014; Kampschreur et al. 2008; Sabba et al. 2015; $\mathrm{Yu}$ et al. 2010). Thus, $\mathrm{N}_{2} \mathrm{O}$ emissions can be significant in processes with anoxic/aerobic stages or intermittent aeration (Chandran et al. 2011).

Unlike $\mathrm{AOB}$, which have well elucidated $\mathrm{N}_{2} \mathrm{O}$ production pathways, the pathways for AOA are yet to be fully understood (Blum et al. 2018b). They perform $\mathrm{NH}_{3}$ oxidation in a similar way to AOB (Kozlowski et al. 2016); however, they lack the ability to produce $\mathrm{N}_{2} \mathrm{O}$ enzymatically through side reactions of $\mathrm{NH}_{3}$ oxidation or nitrifier denitrification, as mediated by AOB (Spang et al. 2012; Tourna et al. 2011; Walker et al. 2010). Stieglmeier et al. (2014) showed that Nitrososphaera viennensis, a pure culture of AOA from soil, produces $\mathrm{N}_{2} \mathrm{O}$ via a hybrid reaction. While AOA are found in WWTPs (Park et al. 2006; Sauder et al. 2012; Zhang et al. 2009), AOA are more common in marine environments (Santoro et al. 2011) and soils (Gubry-Rangin et al. 2010; Li et al. 2018; Nicol et al. 2008; Zhang et al. 2012).

Anammox bacteria convert $\mathrm{NH}_{3}$ and $\mathrm{NO}_{2}{ }^{-}$to $\mathrm{N}_{2}$ under anoxic conditions (Kuypers et al. 2003). NO is a key intermediate in anammox metabolism (Kartal et al. 2011), and genomic 
195 evidence suggests that anammox species have the potential to produce $\mathrm{N}_{2} \mathrm{O}$ via NO reduction 196 (Kartal et al. 2007; Strous et al. 2006). However, research suggests that $\mathrm{N}_{2} \mathrm{O}$ production under 197 process-relevant conditions is negligible (Blum et al. 2018a). Anammox may indirectly affect $198 \mathrm{~N}_{2} \mathrm{O}$ formation by heterotrophs and $\mathrm{AOB}$ by reducing the concentrations of $\mathrm{NH}_{3}$ and $\mathrm{NO}_{2}{ }^{-}$.

199 Comammox bacteria are a subset of the genus Nitrospira capable of complete ammonia 200 oxidation (comammox) via oxidation of $\mathrm{NH}_{3}$ to $\mathrm{NO}_{3}{ }^{-}$(Daims et al. 2015; van Kessel et al. 2015). 201 Comammox are thought to have a competitive advantage over conventional ammonia oxidizers 202 (e.g. AOA and AOB) under ammonia-limiting conditions (Costa et al. 2006; Daims et al. 2015; 203 Kits et al. 2017; van Kessel et al. 2015). While little is known about comammox in wastewater 204 biofilms, van Kessel et al. (2015) and Daims et al. (2015) obtained comammox enrichments in the 205 lab by operating their systems with low $\mathrm{NH}_{3}$ concentrations. Thus, it is likely they play a role in 206 wastewater biofilms under similar conditions.

Evidence suggests that comammox Nitrospira, as opposed to canonical Nitrospira, harbor genomic $\mathrm{NH}_{3}$ and $\mathrm{NO}_{2}{ }^{-}$oxidation machinery homologous to classical $\mathrm{AOB}$ and $\mathrm{NOB}$, respectively 209 (e.g., gene clusters encoding amo, hao, and nxr) (Daims et al. 2015; van Kessel et al. 2015). 210 However, very little is known about their capacity for $\mathrm{N}_{2} \mathrm{O}$ production. $\mathrm{NH}_{2} \mathrm{OH}$ appears to be an 211 obligate intermediate of comammox metabolism, analogous to AOB catabolism, and it is likely 212 that $\mathrm{N}_{2} \mathrm{O}$ can be formed by comammox via the $\mathrm{NH}_{2} \mathrm{OH}$ pathway (Fig. 3). Comammox genomes 213 recovered to date also harbor capacity for $\mathrm{NO}_{2}^{-}$reduction to $\mathrm{NO}$ (NirK), similar to non-comammox 214 Nitrospira (Camejo et al. 2017; Lawson and Lucker 2018). Comammox clades A and B genomes 215 reported to date lack a known NOR or proteins related to NOx metabolism (Palomo et al. 2018), 216 similarly to common Nitrospira taxa (Lawson and Lucker 2018) and therefore may be incapable 217 of nitrifier denitrification. Thus, the presence of reactive nitrogen species produced by comammox 218 biomass, e.g. $\mathrm{NO}$ or $\mathrm{NH}_{2} \mathrm{OH}$, could to lead to abiotic reactions with the production of $\mathrm{N}_{2} \mathrm{O}$ as a 219 final product.

220 Comammox may be detrimental to PN/A systems, where $\mathrm{NO}_{2}^{-}$production is needed. 221 However, they may also reduce $\mathrm{N}_{2} \mathrm{O}$ emissions by minimizing $\mathrm{NO}_{2}{ }^{-}$accumulation. The presence 222 of comammox in wastewater treatment processes, both in suspended growth and biofilm processes, 223 and the metabolic versatility of Nitrospira species including the two comammox Nitrospira clades 224 is currently an active area of research. Future research should also address the selecting factors 
225

226

227

228

229

230

231

232

233

234

235

236

237

238

239

240

241

242

243

244

245

246

247

248

249

250

251

252

253

254

255

for partitioning between comammox and canonical Nitrospira, and clarify the potential role for comammox in $\mathrm{N}_{2} \mathrm{O}$ emissions.

\section{$\mathrm{N}_{2} \mathrm{O}$ from Microorganisms Related to Denitrification}

Denitrification is the sequential reduction of $\mathrm{NO}_{3}{ }^{-}$and $\mathrm{NO}_{2}{ }^{-}$to $\mathrm{NO}, \mathrm{N}_{2} \mathrm{O}$, and finally $\mathrm{N}_{2}$ (Ni and Yuan 2015). It involves four enzymes: the nitrate reductase (NAR), nitrite reductase (NIR), nitric oxide reductase (NOR), and nitrous oxide reductase (NOS). A schematic of the denitrification metabolism is shown in Figure 3.

The formation of $\mathrm{N}_{2} \mathrm{O}$ in wastewater denitrification processes is often due to selective inhibition of the NOS enzyme (Guo et al. 2017). This can be caused by its greater sensitivity to DO (Firestone et al. 1979; Tallec et al. 2008), pH (Firestone et al. 1979; Hanaki et al. 1992), $\mathrm{NO}_{2}{ }^{-}$ (Alinsafi et al. 2008), carbon source type and concentration (Tallec et al. 2006), carbon limitation (Alinsafi et al. 2008; Tallec et al. 2006), and hydrogen sulfide $\left(\mathrm{H}_{2} \mathrm{~S}\right)$ (Schonharting et al. 1998).

While denitrifying bacteria produce $\mathrm{N}_{2} \mathrm{O}$ during denitrification, they also can reduce $\mathrm{N}_{2} \mathrm{O}$ to $\mathrm{N}_{2}$ (Read-Daily et al. 2016). Externally supplied $\mathrm{N}_{2} \mathrm{O}$ can be reduced concurrently with $\mathrm{NO}_{3}{ }^{-}$ and $\mathrm{NO}_{2}^{-}$(Conthe et al. 2018; Pan et al. 2015; Pan et al. 2013a; Read-Daily et al. 2016).

While many denitrifying bacteria have a complete reduction pathway and can reduce $\mathrm{NO}_{3}{ }^{-}$ and $\mathrm{NO}_{2}{ }^{-}$all the way to $\mathrm{N}_{2}$, less is known about bacteria that can grow with $\mathrm{N}_{2} \mathrm{O}$ but not with $\mathrm{NO}_{3}{ }^{-}$ or $\mathrm{NO}_{2}{ }^{-}$. Newly classified clade II-type nosZ $\mathrm{N}_{2} \mathrm{O}$ reducing bacteria were recently discovered (Jones et al. 2013; Sanford et al. 2012). These have since been detected in a granular sludge reactor (Lawson et al. 2017), a membrane-aerated biofilm reactor (MABR) (Kinh et al. 2017b) and a biofiltration system (Yoon et al. 2017). Some isolates harboring clade II type nosZ have higher affinity for $\mathrm{N}_{2} \mathrm{O}$ reduction than those harboring clade I type nosZ (Suenaga et al. 2018; Yoon et al. 2016) whereas a contradictory finding was reported (Conthe et al. 2018), requiring more in-depth analysis concerning bacteria as an $\mathrm{N}_{2} \mathrm{O}$ sink at a low $\mathrm{N}_{2} \mathrm{O}$ concentration. Some clade II type nosZ bacteria appear to lack genes encoding for NIR and/or NOR, suggesting their potential as an $\mathrm{N}_{2} \mathrm{O}$ sink but not an $\mathrm{N}_{2} \mathrm{O}$ source (Graf et al. 2014). As reviewed elsewhere, these non-denitrifying $\mathrm{N}_{2} \mathrm{O}$ reducing bacteria in wastewater engineering are yet to be explored in detail (Hallin et al. 2018). The ecophysiology of non-denitrifying $\mathrm{N}_{2} \mathrm{O}$ reducers in a biofilm system warrants further research. There are a wide range of denitrifying microorganisms, and some with special behavior 
with respect to $\mathrm{N}_{2} \mathrm{O}$ formation and reduction. Some can fully reduce $\mathrm{NO}_{3}{ }^{-}$and $\mathrm{NO}_{2}{ }^{-}$to $\mathrm{NH}_{3}$ in an 257 ecologically important process called dissimilatory nitrate or nitrite reduction to ammonium 258 (DNRA) (Stein and Klotz 2016) (Fig. 2). In this process, $\mathrm{NO}_{3}{ }^{-}$or $\mathrm{NO}_{2}{ }^{-}$is reduced to $\mathrm{NH}_{3}$, with $259 \mathrm{~N}_{2} \mathrm{O}$ produced at the $\mathrm{NO}_{2}{ }^{-}$reduction stage as a by-product (Fig. 2) (Kelso et al. 1997; Rutting et al. 2011; Streminska et al. 2012). Unlike denitrification, this process conserves $\mathrm{N}$ in the ecosystem 261 (Rutting et al. 2011; Tiedje et al. 1982). Many DNRA microorganisms can produce $\mathrm{N}_{2} \mathrm{O}$ as a by262 product (Stevens and Laughlin 1998; Stevens et al. 1998). Some of these microorganisms employ 263 DNRA as a detoxification mechanism in order to avoid high concentration of $\mathrm{NO}_{2}^{-}$(Kaspar 1982). 264 However, the actual contribution of DNRA to $\mathrm{N}_{2} \mathrm{O}$ formation in these species remains uncertain 265 (Butterbach-Bahl et al. 2013).

Behavior regarding $\mathrm{N}_{2} \mathrm{O}$ emissions may also vary based on the type of electron donor. For example, elemental-sulfur ( $\mathrm{S}^{\circ}$ ) oxidizing denitrifiers (Di Capua et al. 2015; Liu et al. 2017b), methane $\left(\mathrm{CH}_{4}\right)$ oxidizing denitrifiers (He et al. 2018), phosphate-accumulating (PAO) denitrifiers (Gao et al. 2017; Wang et al. 2011; Wang et al. 2014; Zhou et al. 2012), $\mathrm{H}_{2}$ oxidizing denitrifiers (Li et al. 2017), and bacteria growing with an electrode as an electron donor (Jiang et al. 2018) display different behavior with respect to $\mathrm{N}_{2} \mathrm{O}$ emissions. Methane-oxidizing denitrifiers appear to reduce $\mathrm{NO}_{2}{ }^{-}$to $\mathrm{N}_{2}$ without forming $\mathrm{N}_{2} \mathrm{O}$ as an intermediate, and therefore are thought to

273 minimize $\mathrm{N}_{2} \mathrm{O}$ emissions (He et al. 2018). While the details on each of these donors are beyond 274 the scope of this review, the kinetics for each donor can have important impacts on $\mathrm{N}_{2} \mathrm{O}$ formation 275 and consumption.

\section{TYPES OF BIOFILM REACTORS AND IMPACTS ON N2O EMISSIONS}

This section describes different type of biofilm reactors, and their special characteristics as relate to $\mathrm{N}_{2} \mathrm{O}$ emissions. Based on the analysis in the previous section, and also following Todt et al. (2016) and Massara et al. (2017), conditions that promote $\mathrm{N}_{2} \mathrm{O}$ emission include (1) low DO values, or DO spatially transitioning from high to low within the biofilm, as this leads to nitrifier denitrification or incomplete heterotrophic denitrification; (2) conditions where the DO fluctuates temporally from high to low values, (3) conditions with high reaction rates, which lead to greater

285 formation of intermediates (e.g., $\mathrm{NH}_{2} \mathrm{OH}, \mathrm{NO}_{2}{ }^{-}$) that promote $\mathrm{N}_{2} \mathrm{O}$ formation; and (4) limiting 286 electron donor for denitrification. 
The above factors may have different impacts for different types of biofilm reactors. There

288 is a wide range of biofilm reactors, and they can be classified based on the arrangement of their

289 solid, liquid, and gas phases, whether the carriers are fixed or moving, their carrier specific surface

290 area (area of carrier per unit volume of reactor), their mixing regime (completely mixed or plug

291 flow), and the mechanisms of transfer of gases and electron donor or acceptor substrates. Typical

292 biofilm reactor configurations are shown schematically in Figure 4.

293

FIGURE 4

295

296

297

298

299

300

301

302

303

304

305

such as odorous compounds in air or volatile organic compounds (VOCs). Air is passed through a

306

307 non-submerged packed bed with biofilms growing on the media, and the contaminants partition

308 into the liquid phase coating the biofilm. Yoon et al. (2017) proposed using a biofilter supplied to

309 remove $\mathrm{N}_{2} \mathrm{O}$ in off gases from an activated sludge aeration basin. Raw wastewater was used as the electron donor. In lab tests, $99.9 \%$ of $\mathrm{N}_{2} \mathrm{O}$ was removed when supplied at $100 \mathrm{ppmV}$ in $\mathrm{N}_{2}$, i.e.,

310 without any $\mathrm{O}_{2}$. However, removals decreased significantly when supplied in air. Biofilters are

311 likely an expensive approach to mitigating $\mathrm{N}_{2} \mathrm{O}$ emissions, as they require covering aeration basin

312 to collect off gases, treating large volumes of gas, and adding an additional process and complexity 313 to the treatment train.

$314 \quad$ Packed bed reactors (Fig. 4B and 4C) are fully submerged fixed bed biofilm reactors. They 315 can be operated in upflow or downflow mode, and either aerated (e.g., for nitrification) or 316 unaerated with electron donor addition (denitrifying filters). Upflow packed bed reactors, such as 317 nitrifying or denitrifying filters, typically operate in plug flow fashion. Thus, the filters experience 
318 high substrate concentrations at the influent end and low concentrations at the effluent end. The 319 concentration gradients (e.g., high $\mathrm{NH}_{3}$ at influent, low $\mathrm{DO}$ at effluent) can impact $\mathrm{N}_{2} \mathrm{O}$ formation 320 processes. When used for denitrification, air pulses are periodically performed at the bottom of the 321 filter to release $\mathrm{N}_{2}$ bubbles accumulating in the reactor. These pulses can strip $\mathrm{N}_{2} \mathrm{O}$ formed at the 322 beginning of the bed, when normally it would be reduced to $\mathrm{N}_{2}$ further within the bed (Bollon et 323 al. 2016). Whenever air is added to a denitrifying filter, there is potential for $\mathrm{N}_{2} \mathrm{O}$ formation at 324 some location within the biofilm due to the greater sensitivity of $\mathrm{N}_{2} \mathrm{OR}$ to $\mathrm{O}_{2}$ inhibition. $\mathrm{N}_{2} \mathrm{O}$ may 325 also accumulate due to insufficient electron donor supply. For nitrifying and denitrifying packed 326 bed reactors, backwashing is carried out regularly to remove excess biomass. Thinner biofilms 327 may not allow full treatment, leading $\mathrm{N}_{2} \mathrm{O}$ breakthrough from the reactor. For denitrifying biofilms, 328 breakthrough can also be caused by donor limitation. Bollon et al. (2016) found that a full-scale 329 denitrifying filter with a $\mathrm{C} / \mathrm{N}$ of 3 or higher had up to $93 \% \mathrm{~N}_{2} \mathrm{O}$ reduction. However, during a 330 carbon supply failure removals lowered 26\%. Similar results were found by Capodici et al. (2018) 331 and Zhang et al. (2016). In the latter study, the authors found that a decrease of the C/N from 3 to 3320.65 led to an increase of the genes encoding for NOR that would enhance the transformation of $333 \mathrm{NO}$ to $\mathrm{N}_{2} \mathrm{O}$ and lead to increased $\mathrm{N}_{2} \mathrm{O}$ emissions. Zhang et al. (2017) studied the behavior of lab334 scale denitrification filters and found a complex interaction of the denitrification with anammox 335 and DNRA. Gene abundance, together with accumulation of $\mathrm{NO}_{2}{ }^{-}$at temperatures between 5 and $33615{ }^{\circ} \mathrm{C}$, were found important factors for $\mathrm{N}_{2} \mathrm{O}$ accumulation. Further research is required to 337 investigate the impact of influent $\mathrm{NO}_{2}{ }^{-}$and possible adaptation of bacteria to variable influent 338 loadings of both $\mathrm{NO}_{2}{ }^{-}$and $\mathrm{NO}_{3}{ }^{-}$in denitrifying filters.

339 RBCs (Fig. 4D) use rotating wheels of media partially submerged in wastewater. When the 340 wheels are outside the water, the biofilm can experience $\mathrm{O}_{2}$ concentrations in the biofilm exterior, 341 while the DO concentrations can drop significantly when immersed in the wastewater (Pynaert et 342 al. 2002). This cycling of high and low DO concentrations, as well variations in donor 343 concentration when the biofilm is submerged vs. when it is out of the wastewater, can potentially 344 lead to higher $\mathrm{N}_{2} \mathrm{O}$ emissions. There does not appear to be any published findings of $\mathrm{N}_{2} \mathrm{O}$ 345 emissions from RBCs. Note that RBCs are often covered to prevent from UV toxicity and to 346 protect from low temperatures in winter. In these cases, it may be possible to pump air from the 347 enclosures through an anoxic zone or into a biofilter, such as that described above, to reduce $\mathrm{N}_{2} \mathrm{O}$ 348 to $\mathrm{N}_{2}$. 
Airlift, MBBRs, and IFAS (Fig. 4E and 4G) use carriers that "float" in the water, and

350

351

352

353

354

355

356

357

358

359

360

361

362

363

364

365

366

367

368

369

370

371

372

373

374

375

376

377

378 therefore have little relative velocity between the carrier and the water. They can be operated under aerobic or anoxic conditions. In continuous systems, the biofilm carriers are kept in a single zone, experiencing consistent bulk environments. This can avoid the high $\mathrm{N}_{2} \mathrm{O}$ emissions in suspended growth systems transitioning from anoxic to aerobic zones (Chandran et al. 2011). Recent research on $\mathrm{N}_{2} \mathrm{O}$ emissions from MBBRs are consistent with the factors described at the beginning of this section, depending on the application (Mannina et al. 2018a; Mannina et al. 2017; Mannina et al. 2018b; Wei et al. 2017).

Fluidized bed reactors (Fig. 4F) behave similarly to a BAF, but use much finer media. This provides a high specific surface area, and allows the particles to become suspended in the upward wastewater flow. These reactors also experience a somewhat higher degree of mixing, compared to packed bed reactors, but still have some plug flow behavior. Excess biofilm is continuously removed by abrasion, and biofilms typically are thinner than in BAFs. The behavior with respect to $\mathrm{N}_{2} \mathrm{O}$ emissions should be similar to the BAFs. Note that aerobic granular sludge can behave similarly to a fluidized bed reactor. However, granular sludge is typically operated in sequencing batch mode (Castro-Barros et al. 2015). Recent research on $\mathrm{N}_{2} \mathrm{O}$ emission from granular sludge also confirm the above mechanisms (Jia et al. 2018; Lu et al. 2018; Peng et al. 2017; Reino et al. 2017).

Counter-diffusional biofilms are those where one substrate diffuses from the bulk liquid, while the other penetrates the biofilm from the attachment surface. The counter-diffusion of substrates leads to a range of different behaviors with respect to conventional, co-diffusional biofilms (Nerenberg, 2016). Examples of counter-diffusional biofilms include MABRs, where the membranes are used to supply air or $\mathrm{O}_{2}$; membrane-biofilm reactors (MBfRs) where membranes supply $\mathrm{H}_{2}$ or $\mathrm{CH}_{4}$ (Liu at al., 2017b); sulfur-based biofilms, where solid $\mathrm{S}^{0}$ particles support a biofilm (Wang et al. 2016a); and even bioelectrochemical biofilms (Jiang et al., 2018). MABR behavior is discuss in more detail in the next section. 

WASTEWASTER TREATMENT

Because of their special layered structure and organization, biofilms allow unique niche formation with specific metabolic functions. In addition, intermediates formed in one biofilm location can diffuse to another with different environments, leading to transformations that would not normally occur in a suspended growth system (Dalsgaard et al. 1995; de Beer 1997; Nielsen et al. 1990; Sabba et al. 2017b; Schreiber et al. 2009). This section discusses basic behavior of biofilms for some key processes, including nitrification, denitrification, combined nitrification and denitrification, and partial nitrification/anammox. The behavior is common for most biofilm reactors except for MABRs, which are described separately. The figures in this section are intended to illustrate typical behavior. They are only schematics, not meant to reflect an actual operating condition.

\section{Nitrifying biofilms}

Nitrifying biofilms form when $\mathrm{NH}_{3}$ is the dominant or sole electron donor. While AOB and NOB are primary population members in nitrifying biofilms, heterotrophic bacteria typically co-exist (Kindaichi et al. 2004), growing on the decay products from nitrifying microorganisms (Gieseke et al. 2005; Okabe et al. 2005). However, $\mathrm{N}_{2} \mathrm{O}$ production in nitrifying biofilms is likely dominated by AOB, with a minor contribution from heterotrophic bacteria. In this section, we focus on the mechanisms of $\mathrm{N}_{2} \mathrm{O}$ from the nitrifying population. In the subsequent section, we discuss the impact of heterotrophs on nitrifying biofilms, especially when organic carbon is present in the 402 bulk.

Typical substrate profiles in nitrifying biofilms, and zones of $\mathrm{N}_{2} \mathrm{O}$ formation and emission, are shown schematically in Figure 5. In conventional, co-diffusional biofilms, the outer biofilm is aerobic and has the highest $\mathrm{NH}_{3}$ concentrations. As a result, the $\mathrm{NH}_{3}$ oxidation rates are high,

406 leading to high $\mathrm{NH}_{2} \mathrm{OH}$ concentrations. In addition, the nitrifier denitrification pathway is 407 inhibited by the high DO in this zone. Thus, the $\mathrm{NH}_{2} \mathrm{OH}$ oxidation pathway is likely to dominate, 408 and $\mathrm{N}_{2} \mathrm{O}$ formation rates are likely to be relatively low. Nitrifier denitrification may become 409 significant in the aerobic/anoxic transition zone (Mao et al. 2008; Schreiber et al. 2009; Schreiber 
410 et al. 2008). In the anoxic zone, $\mathrm{N}_{2} \mathrm{O}$ formation rates are low. This is because $\mathrm{NH}_{3}$ oxidation, 411 which is the source of electrons for nitrifier denitrification, requires $\mathrm{O}_{2}$. However, Sabba et al. 412 (2015) proposed that $\mathrm{NH}_{2} \mathrm{OH}$ formed in the aerobic biofilm exterior would diffuse to the interior 413 anoxic zones. AOB in this zone could utilize $\mathrm{NH}_{2} \mathrm{OH}$ as a rich electron source, enabling the 414 nitrifier denitrification pathway and resulting in a spike of $\mathrm{N}_{2} \mathrm{O}$. Further research is needed to 415 confirm this mechanism experimentally. In Figure 5, the $\mathrm{N}_{2} \mathrm{O}$ concentration profile slopes towards 416 the outer biofilm, indicating diffusive mass transfer towards the bulk. If diffused aeration is used, 417 the $\mathrm{N}_{2} \mathrm{O}$ is readily stripped from the liquid phase (Law et al. 2012; Rassamee et al. 2011; Wu et al. 418 2014).

419 Membrane-aerated biofilms (MABs) are a novel biofilm process for wastewater treatment, 420 where $\mathrm{O}_{2}$ is supplied from the membrane and $\mathrm{NH}_{3}$ from the bulk (Martin and Nerenberg 2012; 421 Syron and Casey 2008) (Fig. 5b). Because of the unique penetration of $\mathrm{NH}_{3}$ and $\mathrm{O}_{2}$ from opposite 422 sides of the biofilm, they are called, as mentioned above counter-diffusional biofilms (Nerenberg 423 2016). $\mathrm{N}_{2} \mathrm{O}$ can also occur in MABRs systems. In MABs, the highest nitrification rates usually 424 occur in the biofilm interior, not at the outer edge. Thus, $\mathrm{N}_{2} \mathrm{O}$ formation via the $\mathrm{NH}_{2} \mathrm{OH}$ pathway 425 is likely to occur in the deep biofilm. In addition, the aerobic/anoxic transition occurs in the 426 biofilm interior, and the bulk is anoxic. Thus, while $\mathrm{N}_{2} \mathrm{O}$ can be stripped from suspended growth 427 systems by bulk aeration (Law et al. 2012; Rassamee et al. 2011; Wu et al. 2014), $\mathrm{N}_{2} \mathrm{O}$ in MABRs 428 can be consumed by denitrifying bacteria in the outer biofilm or bulk liquid. Conversely, some $429 \mathrm{~N}_{2} \mathrm{O}$ may be stripped from MABR biofilms by air flowing through the membrane lumen, if 430 operated with open end membranes (Kinh et al. 2017a). Stripping from the lumen is indicated in 431 Figure $5 b$ by the slope of the $\mathrm{N}_{2} \mathrm{O}$ concentration profile towards the membrane in its proximity.

FIGURE 5

NOB can contribute indirectly to $\mathrm{N}_{2} \mathrm{O}$ emissions by scavenging $\mathrm{DO}$ and favoring the formation of a steeper gradient for transitioning from oxic to anoxic conditions (Sabba et al. 2017a; 437 Sabba et al. 2015). They also can play a key role in reducing the $\mathrm{NO}_{2}{ }^{-}$concentration, which reduces 438 the rates of nitrifier denitrification (Schreiber et al., 2009). Anammox bacteria can play a similar 439 role in decreasing $\mathrm{N}_{2} \mathrm{O}$ emissions (Pellicer-Nacher et al. 2010). As mentioned previously, NOB 
do not play a direct role for $\mathrm{NO}$ and $\mathrm{N}_{2} \mathrm{O}$ emissions, but may affect emission by modifying the

$441 \mathrm{NO}_{2}{ }^{-}$concentrations (Wang et al. 2016b).

442

\section{Denitrifying biofilms}

Denitrifying biofilms are those where $\mathrm{NO}_{3}{ }^{-}$is the primary electron acceptor. We also consider biofilms with an aerobic exterior and denitrifying interior, but neglect any nitrification in the aerobic zone. In denitrifying biofilms, $\mathrm{N}_{2} \mathrm{O}$ is an obligate intermediate. It is typically present at higher concentrations in the outer biofilm region, where $\mathrm{NO}_{3}{ }^{-}$and $\mathrm{NO}_{2}{ }^{-}$reduction activity is higher, but can diffuse and be consumed in deeper regions where $\mathrm{NO}_{3}{ }^{-}$and $\mathrm{NO}_{2}{ }^{-}$concentrations are lower (Fig. 6a). Thus, biofilms can have regions that can serve as an $\mathrm{N}_{2} \mathrm{O}$ sink, mitigating $\mathrm{N}_{2} \mathrm{O}$ emissions (Dalsgaard and Revsbech 1992; Nielsen et al. 1990).

FIGURE 6

In the presence of high DO, denitrification is usually inhibited and therefore little $\mathrm{N}_{2} \mathrm{O}$ is formed (Fig. 6b). However, biofilms typically have DO gradients, and denitrification and $\mathrm{N}_{2} \mathrm{O}$ formation may occur deeper in the biofilm (Dalsgaard and Revsbech 1992; Nielsen et al. 1990).

458 In the transition zone from oxic to anoxic, higher amounts of $\mathrm{N}_{2} \mathrm{O}$ will be formed due to the higher sensitivity of NOS to $\mathrm{O}_{2}$ inhibition (Bonin et al. 1992; Lu and Chandran 2010; Morley et al. 2008; Otte et al. 1996). When this transition zone is near the outer biofilms, more $\mathrm{N}_{2} \mathrm{O}$ may be exported to the bulk liquid. When the transition occurs deeper in the biofilm, i.e., at higher bulk DO concentrations, and when electron donor is sufficient, $\mathrm{N}_{2} \mathrm{O}$ is more likely to be reduced in the deeper biofilm and less emissions will occur (Dalsgaard and Revsbech 1992).

If $\mathrm{N}_{2} \mathrm{O}$ is formed in the outer biofilm, and if sufficient electron donor is available in the deeper zones of the biofilm, denitrifying biofilms can serve as an $\mathrm{N}_{2} \mathrm{O}$ sink (Eldyasti et al. 2014; Sabba et al. 2017b). However, if sulfate reduction occurs in the deeper biofilm where $\mathrm{NO}_{3}{ }^{-}$has 467 been depleted, $\mathrm{H}_{2} \mathrm{~S}$ may accumulate and inhibit $\mathrm{N}_{2} \mathrm{O}$ reduction (Pan et al. 2013b). Electron donor 468 limitation in the denitrifying zone also may result in greater $\mathrm{N}_{2} \mathrm{O}$ formation (Dalsgaard and Revsbech 1992; Nielsen et al. 1990; Todt and Dorsch 2015) (Fig. 6c). 
Biofilms exposed to both organic carbon and $\mathrm{NH}_{3}$ usually have an outer layer dominated by fast-growing heterotrophic bacteria (Henze et al. 2008). In the presence of non-limiting organic substrates, $\mathrm{O}_{2}$ is usually consumed by heterotrophic activity with little formation nitrifying biomass. However, in presence of low or transient organic carbon concentrations, nitrifying organisms can develop in the biofilm. These biofilms are here referred as "combined nitrifying/denitrifying biofilms”.

In combined nitrifying/denitrifying biofilms, the mechanisms of $\mathrm{N}_{2} \mathrm{O}$ formation can be quite complex. Both co- and counter- diffusional combined nitrifying/denitrifying biofilms are characterized by the presence of complex communities where $\mathrm{N}_{2} \mathrm{O}$ is formed by both nitrifiers and denitrifiers, but also reduced by denitrifiers (Matsumoto et al. 2007; Nerenberg 2016). Various intermediates play roles in both pathways, as indicated in Figure 2. For example, $\mathrm{NO}_{2}{ }^{-}$and $\mathrm{NO}$, two crucial components of both nitrifier denitrification and $\mathrm{NH}_{2} \mathrm{OH}$ oxidation pathways, also play a role as intermediates in the denitrification pathway (Todt and Dorsch 2015). Thickness is also a crucial component for both co- and counter- diffusional biofilm, if adequate thickness and COD concentrations are present, then $\mathrm{N}_{2} \mathrm{O}$ reduction can occur (Eldyasti et al. 2014; He et al. 2017). acceptor from the bulk (Fig. 7a). In this type of biofilm, heterotroph are typically more abundant in the outer biofilm, due to their faster growth rates and the greater availability of COD. This zone is typically aerobic, so little or no denitrification or $\mathrm{N}_{2} \mathrm{O}$ reduction occurs. Nitrifiers are typically

492 located in the aerobic zone below the heterotrophs. If enough COD is present, then $\mathrm{N}_{2} \mathrm{O}$ reduction 493 can occur in the deeper biofilm (Fig. 7a) (Chae et al. 2012; Eldyasti et al. 2014; He et al. 2017). 494 When the bulk is aerated in co-diffusional combined nitrifying/denitrifying biofilms, there is 495 greater $\mathrm{N}_{2} \mathrm{O}$ mass transfer towards the bulk rather than towards the anoxic zone where it can be 496 reduced. This translates in higher $\mathrm{N}_{2} \mathrm{O}$ emissions. 
502 would only be active near the membrane surface (Kinh et al. 2017a). In addition, $\mathrm{N}_{2} \mathrm{O}$ formed by 503 the nitrifiers could potentially be reduced by the heterotrophs in outer, anoxic region of the biofilm, 504 where the COD concentrations are highest (Cole et al. 2004; Kinh et al. 2017b; LaPara et al. 2006). 505 As seen for nitrifying biofilms (Fig. 5b), there could also be $\mathrm{N}_{2} \mathrm{O}$ stripping by the membrane, as 506 indicated from a negative slope of the $\mathrm{N}_{2} \mathrm{O}$ profile towards the membrane (Fig. 7b). The lack of

507 bulk aeration reduces $\mathrm{N}_{2} \mathrm{O}$ mass transfer to the bulk. Note that MABR membranes can also strip $508 \mathrm{CO}_{2}$ from the biofilm, leading to $\mathrm{pH}$ shifts that can impact the microbial community and potentially 509 impact $\mathrm{N}_{2} \mathrm{O}$ emissions (Ma et al. 2017b).

510 Based on the above, the type of biofilm (co- vs. counter- diffusional) also can affect the 511 microbial community structure and therefore the $\mathrm{N}_{2} \mathrm{O}$ emissions. For each bulk substrate condition 512 and detachment regime, there may be a different microbial community structure, which in turn can 513 affect the formation/reduction and emissions of $\mathrm{N}_{2} \mathrm{O}$. Therefore, the behavior of these biofilms is 514 complex and hard to predict (Martin and Nerenberg 2012; Nerenberg 2016).

\section{Partial nitritation/anammox biofilms}

In combined partial nitritation/anammox (PN/A) reactors, $\mathrm{NH}_{3}$ is partially oxidized to $\mathrm{NO}_{2}{ }^{-}$

519 by $\mathrm{AOB}$. The remainder of the $\mathrm{NH}_{3}$ is then oxidized to $\mathrm{N}_{2}$ gas via $\mathrm{NO}_{2}{ }^{-}$reduction by anammox 520 bacteria. NOB are undesirable in PN/A reactors, and diverse strategies are employed to outselect 521 these organisms. PN/A reactors typically also harbor a diverse flanking community, many of 522 which are capable of heterotrophic denitrification (Lawson et al. 2017).

523 A distinguishing feature of PN/A systems is the presence of multiple biological sinks for $524 \mathrm{NO}_{2}{ }^{-}$. Biofilm-based PN/A systems are further distinguished by strong spatial segregation of AOB 525 (in oxic layers) and anammox and denitrifiers (in anoxic, usually deep, layers) (Hubaux et al. 2015; 526 Laureni et al. 2016; Okabe et al. 2011). Crossfeeding within the biofilm and capacity of certain 527 denitrifiers to act as internal $\mathrm{N}_{2} \mathrm{O}$ sinks, likely differentiates $\mathrm{N}_{2} \mathrm{O}$ emissions in biofilms from 528 suspended growth PN/A processes.

529 The potential of PN/A systems to act as significant $\mathrm{N}_{2} \mathrm{O}$ sources, particularly from biofilm 530 or hybrid PN/A reactors, is poorly understood. Results suggest that emissions depend strongly on 531 bulk $\mathrm{O}_{2}$ concentration (Harris et al. 2015), $\mathrm{NO}_{2}^{-}$concentration (Van Hulle et al. 2012), $\mathrm{NH}_{3}$ 532 oxidation activity (Blum et al. 2018a; Domingo-Felez et al. 2014), nitrogen loading (Yang et al. 
533 2016), aeration regime (intermittent vs. continuous aeration) (Blum et al. 2018a; Domingo-Felez 534 et al. 2014; Kampschreur et al. 2008; Ma 2018), presence of organic matter (Jia et al. 2018), and 535 biofilm thickness (Vlaeminck et al. 2010b).

536 Intermittent aeration mirrors conditions recently shown to promote $\mathrm{N}_{2} \mathrm{O}$ generation 537 (Chandran et al. 2011; Kampschreur et al. 2008; Kampschreur et al. 2009; Yu et al. 2010), but has 538 also been suggested that appropriate intermittent aeration can facilitate control or minimization of $539 \mathrm{~N}_{2} \mathrm{O}$ emissions from PN/A processes (Castro-Barros et al. 2015; Domingo-Felez et al. 2014; Su et 540 al. 2017).

541 While sources of $\mathrm{N}_{2} \mathrm{O}$ in PN/A systems are still not well understood, multiple studies have 542 indicated it may derive predominantly from AOB. Ali et al. (2016) provided evidence based that 543 nitrifier denitrification and $\mathrm{NH}_{2} \mathrm{OH}$ pathways were equally important to $\mathrm{N}_{2} \mathrm{O}$ formation in the oxic 544 surface region of granules from a PN/A reactor. However, $30 \%$ of $\mathrm{N}_{2} \mathrm{O}$ emissions in this system 545 could be attributed to the anammox dominated anoxic interior of granules due to either 546 heterotrophic denitrification or a yet unidentified pathway. Harris et al. (2015) showed that $\mathrm{N}_{2} \mathrm{O}$ 547 site preference data from a suspended growth PN/A reactor was inconsistent with current 548 understanding of $\mathrm{N}_{2} \mathrm{O}$ production pathways, and further suggested that $\mathrm{N}_{2} \mathrm{O}$ emissions in this 549 system could be due in part to an unknown inorganic or anammox-associated $\mathrm{N}_{2} \mathrm{O}$ production 550 pathway. In general, biofilm-based PN/A processes appear to emit less $\mathrm{N}_{2} \mathrm{O}$ than suspended 551 nitrifying processes (Gilmore et al. 2013). Further research is needed to better identify sources of

$552 \mathrm{~N}_{2} \mathrm{O}$ in biofilm-based and hybrid biofilm suspended growth PN/A systems, and to quantitatively 553 evaluate how spatial structuring, biofilm thickness, and aggregate architecture influence $\mathrm{N}_{2} \mathrm{O}$ 554 emissions in these emerging low energy $\mathrm{N}$ removal systems.

\section{CONCLUSIONS}

$558 \mathrm{~N}_{2} \mathrm{O}$ formation is promoted when there are (1) low DO values, or DO spatially transitioning from 559 high to low within the biofilm; (2) conditions where the DO fluctuates temporally from high to 560 low values; (3) conditions with high reaction rates, which lead to greater formation of 561 intermediates (e.g., $\mathrm{NH}_{2} \mathrm{OH}$ and $\mathrm{NO}_{2}^{-}$) that promote $\mathrm{N}_{2} \mathrm{O}$ formation; and (4) limiting electron 562 donor for denitrification. The microbial basis of $\mathrm{N}_{2} \mathrm{O}$ formation in biofilms and suspended growth 563 systems are similar, yet $\mathrm{N}_{2} \mathrm{O}$ emissions in biofilm systems depend greatly on microbial 
564 stratification, the formation of substrate gradients, the exchange of intermediates within the 565 biofilm, and the type of biofilm reactor. This can lead to different patterns and quantities of $\mathrm{N}_{2} \mathrm{O}$ 566 emission for the same bulk environment, and make it more difficult to predict $\mathrm{N}_{2} \mathrm{O}$ emissions. Co-

567 diffusional and membrane-aerated biofilms may have substantially different behavior, due to the 568 unique microbial and stratifications and substrate profiles. In order to predict $\mathrm{N}_{2} \mathrm{O}$ emissions from 569 biofilm processes, and develop strategies to minimize them, it is important to understand the 570 microbiological and biochemical basis for $\mathrm{N}_{2} \mathrm{O}$ formation, the factors affecting $\mathrm{N}_{2} \mathrm{O}$ formation in 571 biofilms, as well as the impacts of reactor configurations and operating modes. Future research 572 should address the pathways and kinetics of $\mathrm{N}_{2} \mathrm{O}$ emissions from AOA, comammox bacteria, 573 methane-oxidizing denitrifying bacteria, and others. It also is important to explore their abundance 574 in biofilms. Given the complexity of biofilms and biofilm processes, empirical assessments of $\mathrm{N}_{2} \mathrm{O}$ 575 emissions from the broad range of biofilm reactors type and operating conditions is needed, and 576 application-specific recommendations to minimize emissions should be developed.

578 Acknowledgments

579 F.S. and R.N. were partially supported by NSF project CBET0954918 and WERF project U2R10. 580 A. T. was partially funded by Grant-in-Aid for Scientific Research (17H01893) - Japan Society 581 for the Promotion of Science and BFSM was funded by the DFF project N2OMan.

\section{Compliance with Ethical Standards}

584

585 Funding: This study was funded by the Water Environment Research Foundation (grant U2R10), 586 the USA National Science Foundation (grant CBET0954918), the Japanese Society for the 587 Promotion of Science (grant 17H01893), and the Danish Council for Independent (Project 588 N2OMan, File No. 1335-00100B).

590 Conflict of Interest:

591 F. Sabba declares he has no conflict of interest.

592 A. Terada declares he has no conflict of interest.

593 G. Wells declares he has no conflict of interest.

594 B. F. Smets declares he has no conflict of interest. 
R. Nerenberg declares he has no conflict of interest.

Ethical approval:

598 This article does not contain any studies with human participants or animals performed by any of 599 the authors.

\section{REFERENCES}

Ahn JH, Kim S, Park H, Rahm B, Pagilla K, Chandran K (2010) N2O emissions from activated sludge processes, 2008-2009: results of a national monitoring survey in the United States. Environ Sci Technol 44(12):4505-4511

Ali M, Rathnayake RMLD, Zhang L, Ishii S, Kindaichi T, Satoh H, Toyoda S, Yoshida N, Okabe S (2016) Source identification of nitrous oxide emission pathways from a single-stage nitritation-anammox granular reactor. Water Res 102:147-157

Alinsafi A, Adouani N, Beline F, Lendormi T, Limousy L, Sire O (2008) Nitrite effect on nitrous oxide emission from denitrifying activated sludge. Process Biochem 43(6):683-689

Blum J-M, Jensen MM, Smets BF (2018a) Nitrous oxide production in intermittently aerated Partial Nitritation-Anammox reactor: oxic N 2 O production dominates and relates with ammonia removal rate. Chemical Engineering Journal 335:458-466

Blum JM, Su Q, Ma Y, Valverde-Perez B, Domingo-Felez C, Jensen MM, Smets BF (2018b) The $\mathrm{pH}$ dependency of $\mathrm{N}$-converting enzymatic processes, pathways and microbes: effect on net N2 O production. Environ Microbiol 20(5):1623-1640

Bollon J, Filali A, Fayolle Y, Guerin S, Rocher V, Gillot S (2016) Full-scale post denitrifying biofilters: sinks of dissolved N2O? Sci Total Environ 563-564:320-328

Bonin P, Gilewicz M, Bertrand JC (1992) Effects of Oxygen on Pseudomonas-Nautica Growth on N-Alkane with or without Nitrate. Arch Microbiol 157(6):538-545

Butterbach-Bahl K, Baggs EM, Dannenmann M, Kiese R, Zechmeister-Boltenstern S (2013) Nitrous oxide emissions from soils: how well do we understand the processes and their controls? Philos Trans R Soc Lond B Biol Sci 368(1621):20130122

Camejo PY, Santo Domingo J, McMahon KD, Noguera DR (2017) Genome-Enabled Insights into the Ecophysiology of the Comammox Bacterium "Candidatus Nitrospira nitrosa". mSystems 2(5):e00059-00017

Capodici M, Avona A, Laudicina VA, Viviani G (2018) Biological groundwater denitrification systems: Lab-scale trials aimed at nitrous oxide production and emission assessment. Sci Total Environ 630:462-468

Caranto JD, Lancaster KM (2017) Nitric oxide is an obligate bacterial nitrification intermediate produced by hydroxylamine oxidoreductase. Proc Natl Acad Sci U S A 114(31):8217-8222

Caranto JD, Vilbert AC, Lancaster KM (2016) Nitrosomonas europaea cytochrome P460 is a direct link between nitrification and nitrous oxide emission. Proc Natl Acad Sci U S A 113(51):14704-14709

Castro-Barros CM, Daelman MR, Mampaey KE, van Loosdrecht MC, Volcke El (2015) Effect of aeration regime on $\mathrm{N}(2) \mathrm{O}$ emission from partial nitritation-anammox in a full-scale granular sludge reactor. Water Res 68:793-803 
640

641

642

643

644

645

646

647

648

649

650

651

652

653

654

655

656

657

658

659

660

661

662

663

664

665

666

667

668

669

670

671

672

673

674

675

676

677

678

679

680

681

682

683

684

685

686

687

688

689

690

Chae KJ, Kim SM, Oh SE, Ren X, Lee J, Kim IS (2012) Spatial distribution and viability of nitrifying, denitrifying and ANAMMOX bacteria in biofilms of sponge media retrieved from a full-scale biological nutrient removal plant. Bioprocess Biosyst Eng 35(7):1157-1165

Chandran K, Stein LY, Klotz MG, van Loosdrecht MC (2011) Nitrous oxide production by lithotrophic ammonia-oxidizing bacteria and implications for engineered nitrogen-removal systems. Biochem Soc Trans 39(6):1832-1837

Chung YC, Chung MS (2000) BNP test to evaluate the influence of $\mathrm{C} / \mathrm{N}$ ratio on $\mathrm{N} 2 \mathrm{O}$ production in biological denitrification. Water Sci Technol 42(3-4):23-27

Cole AC, Semmens MJ, LaPara TM (2004) Stratification of activity and bacterial community structure in biofilms grown on membranes transferring oxygen. Appl Environ Microbiol 70(4):1982-1989

Conthe M, Wittorf L, Kuenen JG, Kleerebezem R, van Loosdrecht MCM, Hallin S (2018) Life on $\mathrm{N} 2 \mathrm{O}$ : deciphering the ecophysiology of $\mathrm{N} 2 \mathrm{O}$ respiring bacterial communities in a continuous culture. ISME J 12(4):1142-1153

Costa Ec, PĖrez J, Kreft J-U (2006) Why is metabolic labour divided in nitrification? Trends Microbiol 14(5):213-219

Daims H, Lebedeva EV, Pjevac P, Han P, Herbold C, Albertsen M, Jehmlich N, Palatinszky M, Vierheilig J, Bulaev A, Kirkegaard RH, von Bergen M, Rattei T, Bendinger B, Nielsen PH, Wagner M (2015) Complete nitrification by Nitrospira bacteria. Nature 528(7583):504-509

Daims H, Lucker S, Wagner M (2016) A New Perspective on Microbes Formerly Known as NitriteOxidizing Bacteria. Trends Microbiol 24(9):699-712

Dalsgaard T, Dezwart J, Robertson LA, Kuenen JG, Revsbech NP (1995) Nitrification, Denitrification and Growth in Artificial Thiosphaera-Pantotropha Biofilms as Measured with a Combined Microsensor for Oxygen and Nitrous-Oxide. Fems Microbiology Ecology 17(2):137-147

Dalsgaard T, Revsbech NP (1992) Regulating Factors of Denitrification in Trickling Filter Biofilms as Measured with the Oxygen Nitrous-Oxide Microsensor. Fems Microbiology Ecology 101(3):151-164

de Beer D, Stoodley P, Lewandowski Z (1997) Measurement of Local DiffusionCoefficients in Biofilms by Microinjectionand Confocal Microscopy. Biotechnol Bioeng 53(2):151-158

Di Capua F, Papirio S, Lens PNL, Esposito G (2015) Chemolithotrophic denitrification in biofilm reactors. Chemical Engineering Journal 280:643-657

Domingo-Felez C, Mutlu AG, Jensen MM, Smets BF (2014) Aeration strategies to mitigate nitrous oxide emissions from single-stage nitritation/anammox reactors. Environ Sci Technol 48(15):8679-8687

Donlan RM (2002) Biofilms: microbial life on surfaces. Emerg Infect Dis 8(9):881-890

Eldyasti A, Nakhla G, Zhu J (2014) Influence of biofilm thickness on nitrous oxide (N2O) emissions from denitrifying fluidized bed bioreactors (DFBBRs). J Biotechnol 192 Pt A:281-290

Elenter D, Milferstedt K, Zhang W, Hausner M, Morgenroth E (2007) Influence of detachment on substrate removal and microbial ecology in a heterotrophic/autotrophic biofilm. Water Res 41(20):4657-4671

Firestone MK, Smith MS, Firestone RB, Tiedje JM (1979) The Influence of Nitrate, Nitrite, and Oxygen on the Composition of the Gaseous Products of Denitrification in Soil1. Soil Science Society of America Journal 43(6):1140-1144

Flemming HC, Wingender J, Szewzyk U, Steinberg P, Rice SA, Kjelleberg S (2016) Biofilms: an emergent form of bacterial life. Nat Rev Microbiol 14(9):563-575

Gao H, Liu M, Griffin JS, Xu L, Xiang D, Scherson YD, Liu WT, Wells GF (2017) Complete Nutrient Removal Coupled to Nitrous Oxide Production as a Bioenergy Source by Denitrifying Polyphosphate-Accumulating Organisms. Environ Sci Technol 51(8):4531-4540

Gieseke A, Nielsen JL, Amann R, Nielsen PH, de Beer D (2005) In situ substrate conversion and assimilation by nitrifying bacteria in a model biofilm. Environ Microbiol 7(9):1392-1404 
691

692

693

694

695

696

697

698

699

700

701

702

703

704

705

706

707

708

709

710

711

712

713

714

715

716

717

718

719

720

721

722

723

724

725

726

727

728

729

730

731

732

733

734

735

736

737

738

739

740

Gilmore KR, Terada A, Smets BF, Love NG, Garland JL (2013) Autotrophic Nitrogen Removal in a Membrane-Aerated Biofilm Reactor Under Continuous Aeration: A Demonstration. Environ Eng Sci 30(1):38-45

Graf DR, Jones CM, Hallin S (2014) Intergenomic comparisons highlight modularity of the denitrification pathway and underpin the importance of community structure for N2O emissions. PLoS One 9(12):e114118

Gubry-Rangin C, Nicol GW, Prosser JI (2010) Archaea rather than bacteria control nitrification in two agricultural acidic soils. FEMS Microbiol Ecol 74(3):566-574

Guo G, Wang Y, Hao T, Wu D, Chen G-H (2017) Enzymatic nitrous oxide emissions from wastewater treatment. Frontiers of Environmental Science \& Engineering 12(1)

Hallin S, Philippot L, Loffler FE, Sanford RA, Jones CM (2018) Genomics and Ecology of Novel N2O-Reducing Microorganisms. Trends Microbiol 26(1):43-55

Hanaki K, Hong Z, Matsuo T (1992) Production of Nitrous-Oxide Gas during Denitrification of Waste-Water. Water Sci Technol 26(5-6):1027-1036

Harper WF, Takeuchi Y, Riya S, Hosomi M, Terada A (2015) Novel abiotic reactions increase nitrous oxide production during partial nitrification: Modeling and experiments. Chemical Engineering Journal 281:1017-1023

Harris E, Joss A, Emmenegger L, Kipf M, Wolf B, Mohn J, Wunderlin P (2015) Isotopic evidence for nitrous oxide production pathways in a partial nitritation-anammox reactor. Water Res 83:258-270

He Q, Zhu Y, Fan L, Ai H, Huangfu X, Chen M (2017) Effects of $\mathrm{C} / \mathrm{N}$ ratio on nitrous oxide production from nitrification in a laboratory-scale biological aerated filter reactor. Water Sci Technol 75(5-6):1270-1280

He Z, Feng Y, Zhang S, Wang X, Wu S, Pan X (2018) Oxygenic denitrification for nitrogen removal with less greenhouse gas emissions: Microbiology and potential applications. Sci Total Environ 621:453-464

Heil J, Liu SR, Vereecken H, Bruggemann N (2015) Abiotic nitrous oxide production from hydroxylamine in soils and their dependence on soil properties. Soil Biol Biochem 84:107115

Henze M, Loosdrecht MCMv, Ekama GA, Brdjanovic D (2008) Biological Wastewater Treatment - Principles, Modelling and Design IWA Publishing, London

Hubaux N, Wells G, Morgenroth E (2015) Impact of coexistence of flocs and biofilm on performance of combined nitritation-anammox granular sludge reactors. Water Res 68:127-139

Jia MS, Castro-Barros CM, Winkler MKH, Volcke EIP (2018) Effect of organic matter on the performance and $\mathrm{N} 2 \mathrm{O}$ emission of a granular sludge anammox reactor. Environmental Science-Water Research \& Technology 4(7):1035-1046

Jiang X, Ying D, Ye D, Zhang R, Guo Q, Wang Y, Jia J (2018) Electrochemical study of enhanced nitrate removal in wastewater treatment using biofilm electrode. Bioresour Technol 252:134-142

Jones CM, Graf DR, Bru D, Philippot L, Hallin S (2013) The unaccounted yet abundant nitrous oxide-reducing microbial community: a potential nitrous oxide sink. ISME J 7(2):417-426

Kampschreur MJ, Picioreanu C, Tan N, Kleerebezem R, Jetten MS, van Loosdrecht MC (2007) Unraveling the source of nitric oxide emission during nitrification. Water Environ Res 79(13):2499-2509

Kampschreur MJ, Tan NC, Kleerebezem R, Picioreanu C, Jetten MS, Van Loosdrecht MC (2008) Effect of dynamic process conditions on nitrogen oxides emission from a nitrifying culture. Environ Sci Technol 42(2):429-435

Kampschreur MJ, Temmink H, Kleerebezem R, Jetten MS, van Loosdrecht MC (2009) Nitrous oxide emission during wastewater treatment. Water Res 43(17):4093-4103 
741

742

743

744

745

746

747

748

749

750

751

752

753

754

755

756

757

758

759

760

761

762

763

764

765

766

767

768

769

770

771

772

773

774

775

776

777

778

779

780

781

782

783

784

785

786

787

788

789

790

Kartal B, Kuypers MM, Lavik G, Schalk J, Op den Camp HJ, Jetten MS, Strous M (2007) Anammox bacteria disguised as denitrifiers: nitrate reduction to dinitrogen gas via nitrite and ammonium. Environ Microbiol 9(3):635-642

Kartal B, Maalcke WJ, de Almeida NM, Cirpus I, Gloerich J, Geerts W, den Camp HJO, Harhangi HR, Janssen-Megens EM, Francoijs K-J (2011) Molecular mechanism of anaerobic ammonium oxidation. Nature 479(7371):127

Kaspar HF (1982) Nitrite Reduction to Nitrous-Oxide by Propionibacteria - Detoxication Mechanism. Arch Microbiol 133(2):126-130

Kelso B, Smith RV, Laughlin RJ, Lennox SD (1997) Dissimilatory nitrate reduction in anaerobic sediments leading to river nitrite accumulation. Appl Environ Microbiol 63(12):4679-4685

Khan MZ, Mondal PK, Sabir S (2013) Aerobic granulation for wastewater bioremediation: A review. Canadian Journal of Chemical Engineering 91(6):1045-1058

Kim SW, Miyahara M, Fushinobu S, Wakagi T, Shoun H (2010) Nitrous oxide emission from nitrifying activated sludge dependent on denitrification by ammonia-oxidizing bacteria. Bioresour Technol 101(11):3958-3963

Kindaichi T, Ito T, Okabe S (2004) Ecophysiological interaction between nitrifying bacteria and heterotrophic bacteria in autotrophic nitrifying biofilms as determined by microautoradiography-fluorescence in situ hybridization. Applied and Environmental Microbiology 70(3):1641-1650

Kinh CT, Riya S, Hosomi M, Terada A (2017a) Identification of hotspots for NO and N2O production and consumption in counter- and co-diffusion biofilms for simultaneous nitrification and denitrification. Bioresour Technol 245(Pt A):318-324

Kinh CT, Suenaga T, Hori T, Riya S, Hosomi M, Smets BF, Terada A (2017b) Counter-diffusion biofilms have lower $\mathrm{N} 2 \mathrm{O}$ emissions than co-diffusion biofilms during simultaneous nitrification and denitrification: Insights from depth-profile analysis. Water Res 124:363371

Kits KD, Sedlacek CJ, Lebedeva EV, Han P, Bulaev A, Pjevac P, Daebeler A, Romano S, Albertsen M, Stein LY, Daims H, Wagner M (2017) Kinetic analysis of a complete nitrifier reveals an oligotrophic lifestyle. Nature 549(7671):269-272

Kozlowski JA, Stieglmeier M, Schleper C, Klotz MG, Stein LY (2016) Pathways and key intermediates required for obligate aerobic ammonia-dependent chemolithotrophy in bacteria and Thaumarchaeota. ISME J 10(8):1836-1845

Kuypers MM, Sliekers AO, Lavik G, Schmid M, Jorgensen BB, Kuenen JG, Sinninghe Damste JS, Strous M, Jetten MS (2003) Anaerobic ammonium oxidation by anammox bacteria in the Black Sea. Nature 422(6932):608-611

Kuypers MMM, Marchant HK, Kartal B (2018) The microbial nitrogen-cycling network. Nat Rev Microbiol 16(5):263-276

Lackner S, Terada A, Smets BF (2008) Heterotrophic activity compromises autotrophic nitrogen removal in membrane-aerated biofilms: results of a modeling study. Water Res 42(45):1102-1112

LaPara TM, Cole AC, Shanahan JW, Semmens MJ (2006) The effects of organic carbon, ammoniacal-nitrogen, and oxygen partial pressure on the stratification of membraneaerated biofilms. J Ind Microbiol Biotechnol 33(4):315-323

Laureni M, Falas P, Robin O, Wick A, Weissbrodt DG, Nielsen JL, Ternes TA, Morgenroth E, Joss A (2016) Mainstream partial nitritation and anammox: long-term process stability and effluent quality at low temperatures. Water Res 101:628-639

Law Y, Ye L, Pan Y, Yuan Z (2012) Nitrous oxide emissions from wastewater treatment processes. Philos Trans R Soc Lond B Biol Sci 367(1593):1265-1277

Lawson CE, Lucker S (2018) Complete ammonia oxidation: an important control on nitrification in engineered ecosystems? Curr Opin Biotechnol 50:158-165 
791

792

793

794

795

796

797

798

799

800

801

802

803

804

805

806

807

808

809

810

811

812

813

814

815

816

817

818

819

820

821

822

823

824

825

826

827

828

829

830

831

832

833

834

835

836

837

838

839

840

Lawson CE, Wu S, Bhattacharjee AS, Hamilton JJ, McMahon KD, Goel R, Noguera DR (2017) Metabolic network analysis reveals microbial community interactions in anammox granules. Nat Commun 8:15416

Li P, Wang Y, Zuo J, Wang R, Zhao J, Du Y (2017) Nitrogen Removal and N2O Accumulation during Hydrogenotrophic Denitrification: Influence of Environmental Factors and Microbial Community Characteristics. Environ Sci Technol 51(2):870-879

Li YY, Chapman SJ, Nicol GW, Yao HY (2018) Nitrification and nitrifiers in acidic soils. Soil Biol Biochem 116:290-301

Liu S, Han P, Hink L, Prosser JI, Wagner M, Bruggemann N (2017a) Abiotic Conversion of Extracellular $\mathrm{NH} 2 \mathrm{OH}$ Contributes to $\mathrm{N} 2 \mathrm{O}$ Emission during Ammonia Oxidation. Environ Sci Technol 51(22):13122-13132

Liu YW, Ngo HH, Guo WS, Zhou JL, Peng L, Wang DB, Chen XM, Sun J, Ni BJ (2017b) Optimizing sulfur-driven mixotrophic denitrification process: System performance and nitrous oxide emission. Chemical Engineering Science 172:414-422

$\mathrm{Lu} \mathrm{H}$, Chandran K (2010) Factors promoting emissions of nitrous oxide and nitric oxide from denitrifying sequencing batch reactors operated with methanol and ethanol as electron donors. Biotechnol Bioeng 106(3):390-398

Lu X, T DSP, Al-Hazmi HE, Majtacz J, Zhou Q, Xie L, Makinia J (2018) Model-Based Evaluation of N2O Production Pathways in the Anammox-Enriched Granular Sludge Cultivated in a Sequencing Batch Reactor. Environ Sci Technol 52(5):2800-2809

Ma C, Jensen MM, Smets BF, Thamdrup B (2017a) Pathways and Controls of N2O Production in Nitritation-Anammox Biomass. Environ Sci Technol 51(16):8981-8991

Ma $Y$ (2018) Monitoring and modeling of nitrogen conversions in membrane-aerated biofilm reactors: Effects of intermittent aeration. Department of Environmental Engineering, Technical University of Denmark (DTU)

Ma Y, Domingo-Felez C, Plosz BG, Smets BF (2017b) Intermittent Aeration Suppresses NitriteOxidizing Bacteria in Membrane-Aerated Biofilms: A Model-Based Explanation. Environ Sci Technol 51(11):6146-6155

Mannina G, Capodici M, Cosenza A, Di Trapani D (2018a) Nitrous oxide from integrated fixedfilm activated sludge membrane bioreactor: Assessing the influence of operational variables. Bioresour Technol 247:1221-1227

Mannina G, Capodici M, Cosenza A, Laudicina VA, Di Trapani D (2017) The influence of solid retention time on IFAS-MBR systems: Assessment of nitrous oxide emission. J Environ Manage 203(Pt 1):391-399

Mannina G, Ekama GA, Capodici M, Cosenza A, Di Trapani D, Odegaard H, van Loosdrecht MMC (2018b) Influence of carbon to nitrogen ratio on nitrous oxide emission in an Integrated Fixed Film Activated Sludge Membrane BioReactor plant. Journal of Cleaner Production 176:1078-1090

Mao Y, Bakken LR, Zhao L, Frostegard A (2008) Functional robustness and gene pools of a wastewater nitrification reactor: comparison of dispersed and intact biofilms when stressed by low oxygen and low pH. FEMS Microbiol Ecol 66(1):167-180

Martin KJ, Nerenberg R (2012) The membrane biofilm reactor (MBfR) for water and wastewater treatment: principles, applications, and recent developments. Bioresour Technol 122:8394

Massara TM, Malamis S, Guisasola A, Baeza JA, Noutsopoulos C, Katsou E (2017) A review on nitrous oxide (N2O) emissions during biological nutrient removal from municipal wastewater and sludge reject water. Sci Total Environ 596-597:106-123

Matsumoto S, Terada A, Tsuneda S (2007) Modeling of membrane-aerated biofilm: Effects of C/N ratio, biofilm thickness and surface loading of oxygen on feasibility of simultaneous nitrification and denitrification. Biochemical Engineering Journal 37(1):98-107 
841

842

843

844

845

846

847

848

849

850

851

852

853

854

855

856

857

858

859

860

861

862

863

864

865

866

867

868

869

870

871

872

873

874

875

876

877

878

879

880

881

882

883

884

885

886

887

888

889

890

Melse RW, Mosquera J (2014) Nitrous oxide (N2O) emissions from biotrickling filters used for ammonia removal at livestock facilities. Water Sci Technol 69(5):994-1003

Montzka SA, Dlugokencky EJ, Butler JH (2011) Non-CO2 greenhouse gases and climate change. Nature 476(7358):43-50

Morgenroth E (2008) Biofilm reactors. In: Henze M, vanLoosdrecht MCM, Ekama GA, Brdjanovic D (eds) Biological wastewater treatment. IWA Publishing:457-492

Morley N, Baggs EM, Dorsch P, Bakken L (2008) Production of NO, N2O and N2 by extracted soil bacteria, regulation by NO2(-) and O2 concentrations. FEMS Microbiol Ecol 65(1):102112

Nerenberg R (2016) The membrane-biofilm reactor (MBfR) as a counter-diffusional biofilm process. Curr Opin Biotechnol 38:131-136

$\mathrm{Ni} \mathrm{BJ}$, Yuan Z (2015) Recent advances in mathematical modeling of nitrous oxides emissions from wastewater treatment processes. Water Res 87:336-346

Nicol GW, Leininger S, Schleper C, Prosser JI (2008) The influence of soil pH on the diversity, abundance and transcriptional activity of ammonia oxidizing archaea and bacteria. Environ Microbiol 10(11):2966-2978

Nicolella C, van Loosdrecht MC, Heijnen JJ (2000) Wastewater treatment with particulate biofilm reactors. J Biotechnol 80(1):1-33

Nielsen LP, Christensen PB, Revsbech NP, Sorensen J (1990) Denitrification and oxygen respiration in biofilms studied with a microsensor for nitrous oxide and oxygen. Microb Ecol 19(1):63-72

Okabe S, Kindaichi T, Ito T (2005) Fate of 14C-labeled microbial products derived from nitrifying bacteria in autotrophic nitrifying biofilms. Appl Environ Microbiol 71(7):3987-3994

Okabe S, Oshiki M, Takahashi Y, Satoh H (2011) N2O emission from a partial nitrificationanammox process and identification of a key biological process of $\mathrm{N} 2 \mathrm{O}$ emission from anammox granules. Water Res 45(19):6461-6470

Otte S, Grobben NG, Robertson LA, Jetten MS, Kuenen JG (1996) Nitrous oxide production by Alcaligenes faecalis under transient and dynamic aerobic and anaerobic conditions. Appl Environ Microbiol 62(7):2421-2426

Palomo A, Pedersen AG, Fowler SJ, Dechesne A, Sicheritz-Ponten T, Smets BF (2018) Comparative genomics sheds light on niche differentiation and the evolutionary history of comammox Nitrospira. ISME J 12(7):1779-1793

Pan Y, Ni BJ, Lu H, Chandran K, Richardson D, Yuan Z (2015) Evaluating two concepts for the modelling of intermediates accumulation during biological denitrification in wastewater treatment. Water Res 71:21-31

Pan Y, Ni BJ, Yuan Z (2013a) Modeling electron competition among nitrogen oxides reduction and $\mathrm{N} 2 \mathrm{O}$ accumulation in denitrification. Environ Sci Technol 47(19):11083-11091

Pan Y, Ye L, Yuan Z (2013b) Effect of $\mathrm{H} 2 \mathrm{~S}$ on N2O reduction and accumulation during denitrification by methanol utilizing denitrifiers. Environ Sci Technol 47(15):8408-8415

Park HD, Wells GF, Bae H, Criddle CS, Francis CA (2006) Occurrence of ammonia-oxidizing archaea in wastewater treatment plant bioreactors. Appl Environ Microbiol 72(8):56435647

Park KY, Inamori Y, Mizuochi M, Ahn KH (2000) Emission and control of nitrous oxide from a biological wastewater treatment system with intermittent aeration. J Biosci Bioeng 90(3):247-252

Pellicer-Nacher C, Sun S, Lackner S, Terada A, Schreiber F, Zhou Q, Smets BF (2010) Sequential aeration of membrane-aerated biofilm reactors for high-rate autotrophic nitrogen removal: experimental demonstration. Environ Sci Technol 44(19):7628-7634

Peng L, Sun J, Liu Y, Dai X, Ni BJ (2017) Nitrous Oxide Production in a Granule-based Partial Nitritation Reactor: A Model-based Evaluation. Sci Rep 7:45609 
891

892

893

894

895

896

897

898

899

900

901

902

903

904

905

906

907

908

909

910

911

912

913

914

915

916

917

918

919

920

921

922

923

924

925

926

927

928

929

930

931

932

933

934

935

936

937

938

939

940

Pynaert K, Sprengers R, Laenen J, Verstraete W (2002) Oxygen-limited nitrification and denitrification in a lab-scale rotating biological contactor. Environ Technol 23(3):353-362

Rassamee V, Sattayatewa C, Pagilla K, Chandran K (2011) Effect of oxic and anoxic conditions on nitrous oxide emissions from nitrification and denitrification processes. Biotechnol Bioeng 108(9):2036-2045

Read-Daily BL, Sabba F, Pavissich JP, Nerenberg R (2016) Kinetics of nitrous oxide (N2O) formation and reduction by Paracoccus pantotrophus. AMB Express 6(1):85

Reino C, van Loosdrecht MCM, Carrera J, Perez J (2017) Effect of temperature on N2O emissions from a highly enriched nitrifying granular sludge performing partial nitritation of a lowstrength wastewater. Chemosphere 185:336-343

Ritter WF, Chitikela, SR (2014) Greenhouse Gas Emissions from Wastewater Treatment Plants and By-Product Operations - A Comprehensive Review World Environmental and Water Resources Congress 2014.

Rutting T, Boeckx P, Muller C, Klemedtsson L (2011) Assessment of the importance of dissimilatory nitrate reduction to ammonium for the terrestrial nitrogen cycle. Biogeosciences 8(7):1779-1791

Sabba F, Picioreanu C, Boltz JP, Nerenberg R (2017a) Predicting N2O emissions from nitrifying and denitrifying biofilms: a modeling study. Water Sci Technol 75(3-4):530-538

Sabba F, Picioreanu C, Nerenberg R (2017b) Mechanisms of nitrous oxide (N2 O) formation and reduction in denitrifying biofilms. Biotechnol Bioeng 114(12):2753-2761

Sabba F, Picioreanu C, Perez J, Nerenberg R (2015) Hydroxylamine diffusion can enhance N(2)O emissions in nitrifying biofilms: a modeling study. Environ Sci Technol 49(3):1486-1494

Sanford RA, Wagner DD, Wu Q, Chee-Sanford JC, Thomas SH, Cruz-Garcia C, Rodriguez G, Massol-Deya A, Krishnani KK, Ritalahti KM, Nissen S, Konstantinidis KT, Loffler FE (2012) Unexpected nondenitrifier nitrous oxide reductase gene diversity and abundance in soils. Proc Natl Acad Sci U S A 109(48):19709-19714

Santoro AE, Buchwald C, Mcllvin MR, Casciotti KL (2011) Isotopic signature of N(2)O produced by marine ammonia-oxidizing archaea. Science 333(6047):1282-1285

Sauder LA, Peterse F, Schouten S, Neufeld JD (2012) Low-ammonia niche of ammonia-oxidizing archaea in rotating biological contactors of a municipal wastewater treatment plant. Environ Microbiol 14(9):2589-2600

Schonharting B, Rehner R, Metzger JW, Krauth K, Rizzi M (1998) Release of nitrous oxide (No) from denitrifying activated sludge caused by Hs-containing wastewater: Quantification and application of a new mathematical model. Water Sci Technol 38(1):237-246

Schreiber F, Loeffler B, Polerecky L, Kuypers MM, de Beer D (2009) Mechanisms of transient nitric oxide and nitrous oxide production in a complex biofilm. ISME J 3(11):1301-1313

Schreiber F, Polerecky L, de Beer D (2008) Nitric oxide microsensor for high spatial resolution measurements in biofilms and sediments. Anal Chem 80(4):1152-1158

Schreiber F, Wunderlin P, Udert KM, Wells GF (2012) Nitric oxide and nitrous oxide turnover in natural and engineered microbial communities: biological pathways, chemical reactions, and novel technologies. Front Microbiol 3:372

Soler-Jofra A, Picioreanu C, Yu R, Chandran K, van Loosdrecht MCM, Pérez J (2018) Importance of hydroxylamine in abiotic $\mathrm{N} 2 \mathrm{O}$ production during transient anoxia in planktonic axenic Nitrosomonas cultures. Chemical Engineering Journal 335:756-762

Soler-Jofra A, Stevens B, Hoekstra M, Picioreanu C, Sorokin D, van Loosdrecht MCM, Perez J (2016) Importance of abiotic hydroxylamine conversion on nitrous oxide emissions during nitritation of reject water. Chemical Engineering Journal 287:720-726

Spang A, Poehlein A, Offre P, Zumbragel S, Haider S, Rychlik N, Nowka B, Schmeisser C, Lebedeva EV, Rattei T, Bohm C, Schmid M, Galushko A, Hatzenpichler R, Weinmaier T, Daniel R, Schleper C, Spieck E, Streit W, Wagner M (2012) The genome of the ammonia- 
941

942

943

944

945

946

947

948

949

950

951

952

953

954

955

956

957

958

959

960

961

962

963

964

965

966

967

968

969

970

971

972

973

974

975

976

977

978

979

980

981

982

983

984

985

986

987

988

989

990

991

oxidizing Candidatus Nitrososphaera gargensis: insights into metabolic versatility and environmental adaptations. Environ Microbiol 14(12):3122-3145

Spott O, Russow R, Stange CF (2011) Formation of hybrid N2O and hybrid N2 due to codenitrification: First review of a barely considered process of microbially mediated $\mathrm{N}$ nitrosation. Soil Biology and Biochemistry 43(10):1995-2011

Spott O, Stange CF (2011) Formation of hybrid N2O in a suspended soil due to co-denitrification of $\mathrm{NH} 2 \mathrm{OH}$. J Plant Nutr Soil Sc 174(4):554-567

Stein LY (2011) Surveying N2O-producing pathways in bacteria. Methods Enzymol 486:131-152

Stein LY, Klotz MG (2016) The nitrogen cycle. Curr Biol 26(3):R94-98

Stevens RJ, Laughlin RJ (1998) Measurement of nitrous oxide and di-nitrogen emissions from agricultural soils. Nutr Cycl Agroecosys 52(2-3):131-139

Stevens RJ, Laughlin RJ, Malone JP (1998) Soil pH affects the processes reducing nitrate to nitrous oxide and di-nitrogen. Soil Biol Biochem 30(8-9):1119-1126

Stieglmeier M, Mooshammer M, Kitzler B, Wanek W, Zechmeister-Boltenstern S, Richter A, Schleper C (2014) Aerobic nitrous oxide production through N-nitrosating hybrid formation in ammonia-oxidizing archaea. ISME J 8(5):1135-1146

Stoodley P, Sauer K, Davies DG, Costerton JW (2002) Biofilms as complex differentiated communities. Annu Rev Microbiol 56:187-209

Streminska MA, Felgate H, Rowley G, Richardson DJ, Baggs EM (2012) Nitrous oxide production in soil isolates of nitrate-ammonifying bacteria. Environmental microbiology reports 4(1):66-71

Strous M, Pelletier E, Mangenot S, Rattei T, Lehner A, Taylor MW, Horn M, Daims H, BartolMavel D, Wincker P, Barbe V, Fonknechten N, Vallenet D, Segurens B, SchenowitzTruong C, Medigue C, Collingro A, Snel B, Dutilh BE, Op den Camp HJM, van der Drift C, Cirpus I, van de Pas-Schoonen KT, Harhangi HR, van Niftrik L, Schmid M, Keltjens J, van de Vossenberg J, Kartal B, Meier H, Frishman D, Huynen MA, Mewes HW, Weissenbach J, Jetten MSM, Wagner M, Le Paslier D (2006) Deciphering the evolution and metabolism of an anammox bacterium from a community genome. Nature 440(7085):790-794

Su Q, Ma C, Domingo-Felez C, Kiil AS, Thamdrup B, Jensen MM, Smets BF (2017) Low nitrous oxide production through nitrifier-denitrification in intermittent-feed high-rate nitritation reactors. Water Res 123:429-438

Suenaga T, Riya S, Hosomi M, Terada A (2018) Biokinetic Characterization and Activities of N2OReducing Bacteria in Response to Various Oxygen Levels. Front Microbiol 9:697

Syron E, Casey E (2008) Membrane-aerated biofilms for high rate biotreatment: performance appraisal, engineering principles, scale-up, and development requirements. Environ Sci Technol 42(6):1833-1844

Tallec G, Garnier J, Billen G, Gousailles M (2006) Nitrous oxide emissions from secondary activated sludge in nitrifying conditions of urban wastewater treatment plants: effect of oxygenation level. Water Res 40(15):2972-2980

Tallec G, Garnier J, Billen G, Gousailles M (2008) Nitrous oxide emissions from denitrifying activated sludge of urban wastewater treatment plants, under anoxia and low oxygenation. Bioresour Technol 99(7):2200-2209

Terada A, Sugawara S, Hojo K, Takeuchi Y, Riya S, Harper WF, Jr., Yamamoto T, Kuroiwa M, Isobe K, Katsuyama C, Suwa Y, Koba K, Hosomi M (2017) Hybrid Nitrous Oxide Production from a Partial Nitrifying Bioreactor: Hydroxylamine Interactions with Nitrite. Environ Sci Technol 51(5):2748-2756

Tiedje JM, Sexstone AJ, Myrold DD, Robinson JA (1982) Denitrification: ecological niches, competition and survival. Antonie van Leeuwenhoek 48(6):569-583

Todt D, Dorsch P (2015) Nitrous oxide emissions in a biofilm loaded with different mixtures of concentrated household wastewater. International Journal of Environmental Science and Technology 12(11):3405-3416 
992

993

994

995

996

997

998

999

1000

1001

1002

1003

1004

1005

1006

1007

1008

1009

1010

1011

1012

1013

1014

1015

1016

1017

1018

1019

1020

1021

1022

1023

1024

1025

1026

1027

1028

1029

1030

1031

1032

1033

1034

1035

1036

1037

1038

1039

1040

1041

Todt D, Dorsch P (2016) Mechanism leading to N2O production in wastewater treating biofilm systems. Rev Environ Sci Bio 15(3):355-378

Tourna M, Stieglmeier M, Spang A, Konneke M, Schintlmeister A, Urich T, Engel M, Schloter M, Wagner M, Richter A, Schleper C (2011) Nitrososphaera viennensis, an ammonia oxidizing archaeon from soil. Proc Natl Acad Sci U S A 108(20):8420-8425

Van Hulle SWH, Callens J, Mampaey KE, van Loosdrecht MCM, Volcke EIP (2012) N2O and NO emissions during autotrophic nitrogen removal in a granular sludge reactor - a simulation study. Environ Technol 33(20):2281-2290

van Kessel MAHJ, Speth DR, Albertsen M, Nielsen PH, Op den Camp HJM, Kartal B, Jetten MSM, Lücker S (2015) Complete nitrification by a single microorganism. Nature 528(7583):555-559

Vlaeminck SE, Terada A, Smets BF, De Clippeleir H, Schaubroeck T, Bolca S, Demeestere L, Mast J, Boon N, Carballa M, Verstraete W (2010a) Aggregate size and architecture determine microbial activity balance for one-stage partial nitritation and anammox. Appl Environ Microbiol 76(3):900-909

Vlaeminck SE, Terada A, Smets BF, De Clippeleir H, Schaubroeck T, Bolca S, Demeestere L, Mast J, Boon N, Carballa M, Verstraete W (2010b) Aggregate Size and Architecture Determine Microbial Activity Balance for One-Stage Partial Nitritation and Anammox. Appl Environ Microbiol 76(3):900-909

Vroom JM, De Grauw KJ, Gerritsen HC, Bradshaw DJ, Marsh PD, Watson GK, Birmingham JJ, Allison C (1999) Depth penetration and detection of pH gradients in biofilms by two-photon excitation microscopy. Appl Environ Microbiol 65(8):3502-3511

Walker CB, de la Torre JR, Klotz MG, Urakawa H, Pinel N, Arp DJ, Brochier-Armanet C, Chain PS, Chan PP, Gollabgir A, Hemp J, Hugler M, Karr EA, Konneke M, Shin M, Lawton TJ, Lowe T, Martens-Habbena W, Sayavedra-Soto LA, Lang D, Sievert SM, Rosenzweig AC, Manning G, Stahl DA (2010) Nitrosopumilus maritimus genome reveals unique mechanisms for nitrification and autotrophy in globally distributed marine crenarchaea. Proc Natl Acad Sci U S A 107(19):8818-8823

Wang Y, Bott C, Nerenberg R (2016a) Sulfur-based denitrification: Effect of biofilm development on denitrification fluxes. Water Res 100:184-193

Wang Y, Geng J, Ren Z, He W, Xing M, Wu M, Chen S (2011) Effect of anaerobic reaction time on denitrifying phosphorus removal and $\mathrm{N} 2 \mathrm{O}$ production. Bioresour Technol 102(10):5674-5684

Wang Y, Zhou S, Ye L, Wang H, Stephenson T, Jiang X (2014) Nitrite survival and nitrous oxide production of denitrifying phosphorus removal sludges in long-term nitrite/nitrate-fed sequencing batch reactors. Water Res 67:33-45

Wang YY, Fang HY, Zhou D, Han HC, Chen J (2016b) Characterization of nitrous oxide and nitric oxide emissions from a full-scale biological aerated filter for secondary nitrification. Chemical Engineering Journal 299:304-313

WEF (2010) Biofilm Reactors WEF MOP 35. McGraw-Hill Education

Wei D, Zhang K, Ngo HH, Guo W, Wang S, Li J, Han F, Du B, Wei Q (2017) Nitrogen removal via nitrite in a partial nitrification sequencing batch biofilm reactor treating high strength ammonia wastewater and its greenhouse gas emission. Bioresour Technol 230:49-55

Wu GX, Zheng DR, Xing LZ (2014) Nitritation and N2O Emission in a Denitrification and Nitrification Two-Sludge System Treating High Ammonium Containing Wastewater. Water-Sui 6(10):2978-2992

Xavier JB, Picioreanu C, van Loosdrecht MC (2005) A framework for multidimensional modelling of activity and structure of multispecies biofilms. Environ Microbiol 7(8):1085-1103

Yang J, Trela J, Plaza E (2016) Nitrous oxide emissions from one-step partial nitritation/anammox processes. Water Sci Technol 74(12):2870-2878 
Yoon H, Song MJ, Yoon S (2017) Design and Feasibility Analysis of a Self-Sustaining Biofiltration System for Removal of Low Concentration N2O Emitted from Wastewater Treatment Plants. Environ Sci Technol 51(18):10736-10745

Yoon S, Nissen S, Park D, Sanford RA, Loffler FE (2016) Nitrous Oxide Reduction Kinetics Distinguish Bacteria Harboring Clade I NosZ from Those Harboring Clade II NosZ. Appl Environ Microbiol 82(13):3793-3800

Yu R, Kampschreur MJ, van Loosdrecht MCM, Chandran K (2010) Mechanisms and Specific Directionality of Autotrophic Nitrous Oxide and Nitric Oxide Generation during Transient Anoxia. Environmental Science \& Technology 44(4):1313-1319

Zhang LM, Hu HW, Shen JP, He JZ (2012) Ammonia-oxidizing archaea have more important role than ammonia-oxidizing bacteria in ammonia oxidation of strongly acidic soils. ISME J 6(5):1032-1045

Zhang T, Jin T, Yan Q, Shao M, Wells G, Criddle C, HH PF (2009) Occurrence of ammoniaoxidizing Archaea in activated sludges of a laboratory scale reactor and two wastewater treatment plants. J Appl Microbiol 107(3):970-977

Zhang Y, Ji G, Wang R (2016) Drivers of nitrous oxide accumulation in denitrification biofilters with low carbon:nitrogen ratios. Water Res 106:79-85

Zhang Y, Ji GD, Wang RJ (2017) Quantitative responses of nitrous oxide accumulation to genetic associations across a temperature gradient within denitrification biofilters. Ecological Engineering 102:145-151

Zhou Y, Lim M, Harjono S, Ng WJ (2012) Nitrous oxide emission by denitrifying phosphorus removal culture using polyhydroxyalkanoates as carbon source. Journal of Environmental Sciences 24(9):1616-1623 
Fig. 1 Idealized schematics of (a) a floc, and (b) a biofilm. The biofilm schematic shows the liquid diffusion layer (LDL), as well as profiles of a substrate and metabolic product. Note that real flocs are highly complex and heterogeneous in morphology, and biofilms may have rough or dendritic surfaces with internal pores.

Fig. 2 Key processes in the $\mathrm{N}$-cycle. $\mathrm{N}_{2} \mathrm{O}$ is highlighted in gray (adapted from Daims et al. 2016 and Schreiber et al. 2012). The dashed line for comammox shows the formation of $\mathrm{NO}_{2}^{-}$as intermediate but also its oxidation to $\mathrm{NO}_{3}{ }^{-}$by the same organism. Abbreviations in figure: DNRA is dissimilatory nitrite reduction to ammonia; assimil. is assimilatory; dissimil. is dissimilatory. Note that denitrification can produce $\mathrm{N}_{2} \mathrm{O}$, but it is also the only known process that can reduce it.

Fig. 3 Nitrogen transformations in AOB, NOB and DNB. Abbreviations: AOB, ammoniaoxidizing bacteria; NOB, nitrite-oxidizing bacteria; DNB, denitrifying bacteria, AMO, ammonia monooxygenase; HAO, hydroxylamine oxidoreductase (hydroxylamine dehydrogenase in Nitrospira); NXR, nitrite oxidoreductase; NirK, copper-containing nitrite reductase; NirS, cytochrome cd1 type nitrite reductase; NOR, nitric oxide reductase; and NOS, nitrous oxide reductase. Purple arrows show intermediates potentially shared between nitrification and denitrification pathways. Abiotic reactions (gray) are further discussed in the text.

Fig. 4 Types of biofilm reactors. (A) Unsubmerged filter (e.g., trickling filter or biofilter), (B) upflow fixed-bed reactor (e.g., biologically active filter (BAF), (C) downflow fixed-bed reactor (e.g., BAF), (D) rotating biological contactor (RBC), (E) suspended or airlift biofilm reactor, (F) fluidized-bed biofilm reactor (FBBR or granular sludge), (G) moving-bed biofilm reactor (MBBR), integrated fixed film activated sludge (IFAS), and $(\mathrm{H})$ membrane-supported biofilm reactor (e.g., MBfR or MABR). Note: $i=$ influent; $e=$ effluent; $r=$ recycle; $w=$ wasting flow; $g$ = gas flow (typically air) in or out. Black dots in figures E, F, and G are biofilm carriers. Adapted from (Morgenroth 2008) and (WEF 2010)

Fig. $5 \mathrm{~N}_{2} \mathrm{O}$ formation in nitrifying biofilms. (a) Co-diffusional and (b) counter-diffusional. Solid black arrow indicates $\mathrm{N}_{2} \mathrm{O}$ loss towards either bulk or membrane lumen. $\mathrm{NO}_{2}{ }^{-}$and $\mathrm{NO}$ are not shown for clarity.

Fig. $6 \mathrm{~N}_{2} \mathrm{O}$ formation in denitrifying biofilms. (a) Excess $\mathrm{e}^{-}$donor, (b) excess $\mathrm{e}^{-}$donor with $\mathrm{O}_{2}$, and (c) limiting $\mathrm{e}^{-}$donor. Solid black arrow indicates $\mathrm{N}_{2} \mathrm{O}$ loss towards bulk and dashed black arrow indicates reduction within the biofilm depth. $\mathrm{NO}_{2}{ }^{-}$and $\mathrm{NO}$ are not shown for clarity.

Fig. $7 \mathrm{~N}_{2} \mathrm{O}$ formation in combined nitrifying/denitrifying biofilms. (a) Co-diffusional and (b) counter-diffusional. Solid black arrow indicates $\mathrm{N}_{2} \mathrm{O}$ loss towards either bulk or membrane lumen; dashed black arrow indicates reduction within the biofilm depth. $\mathrm{NO}_{2}{ }^{-}$and $\mathrm{NO}$ are not shown for clarity 
(a)

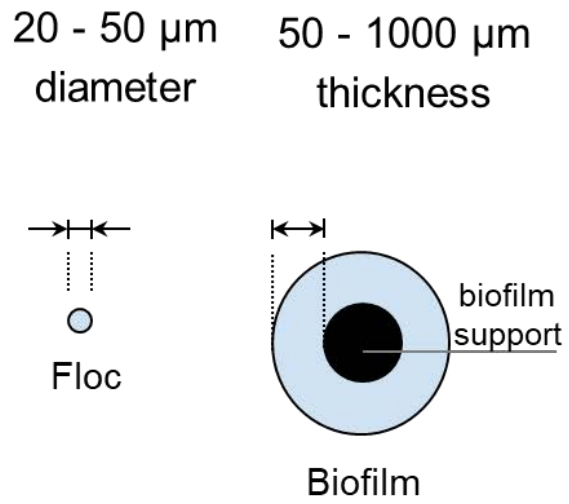

(b)

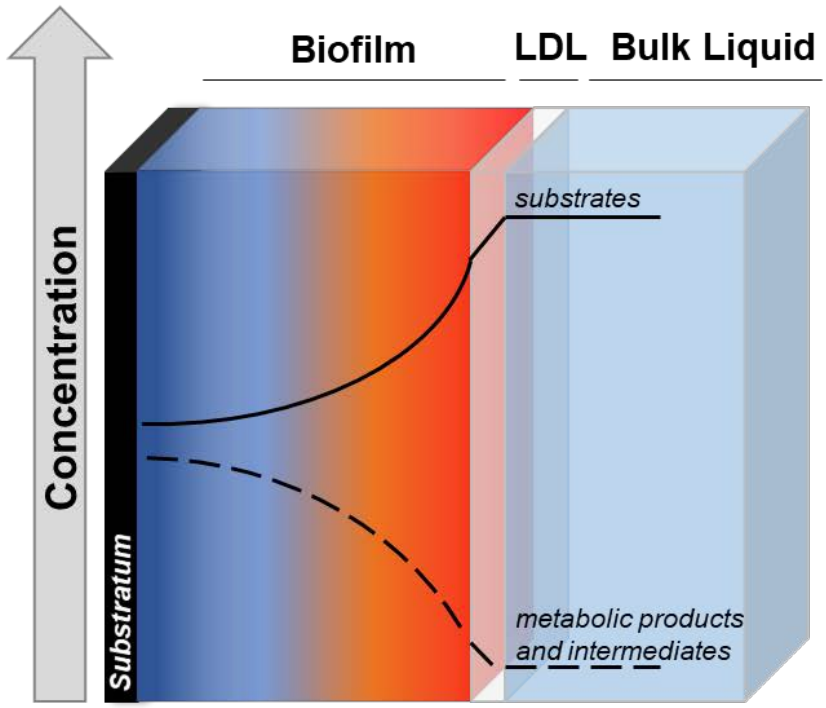

Distance from attachment surface 


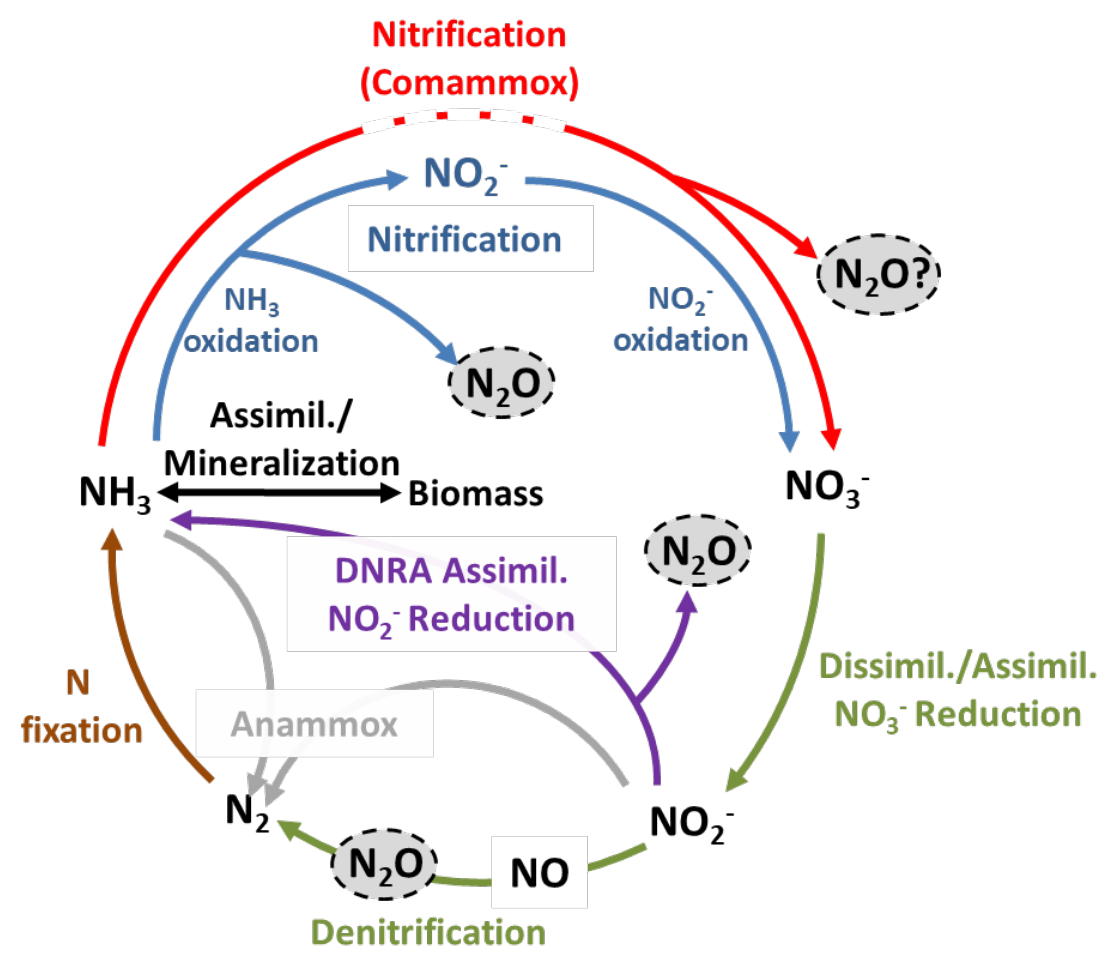




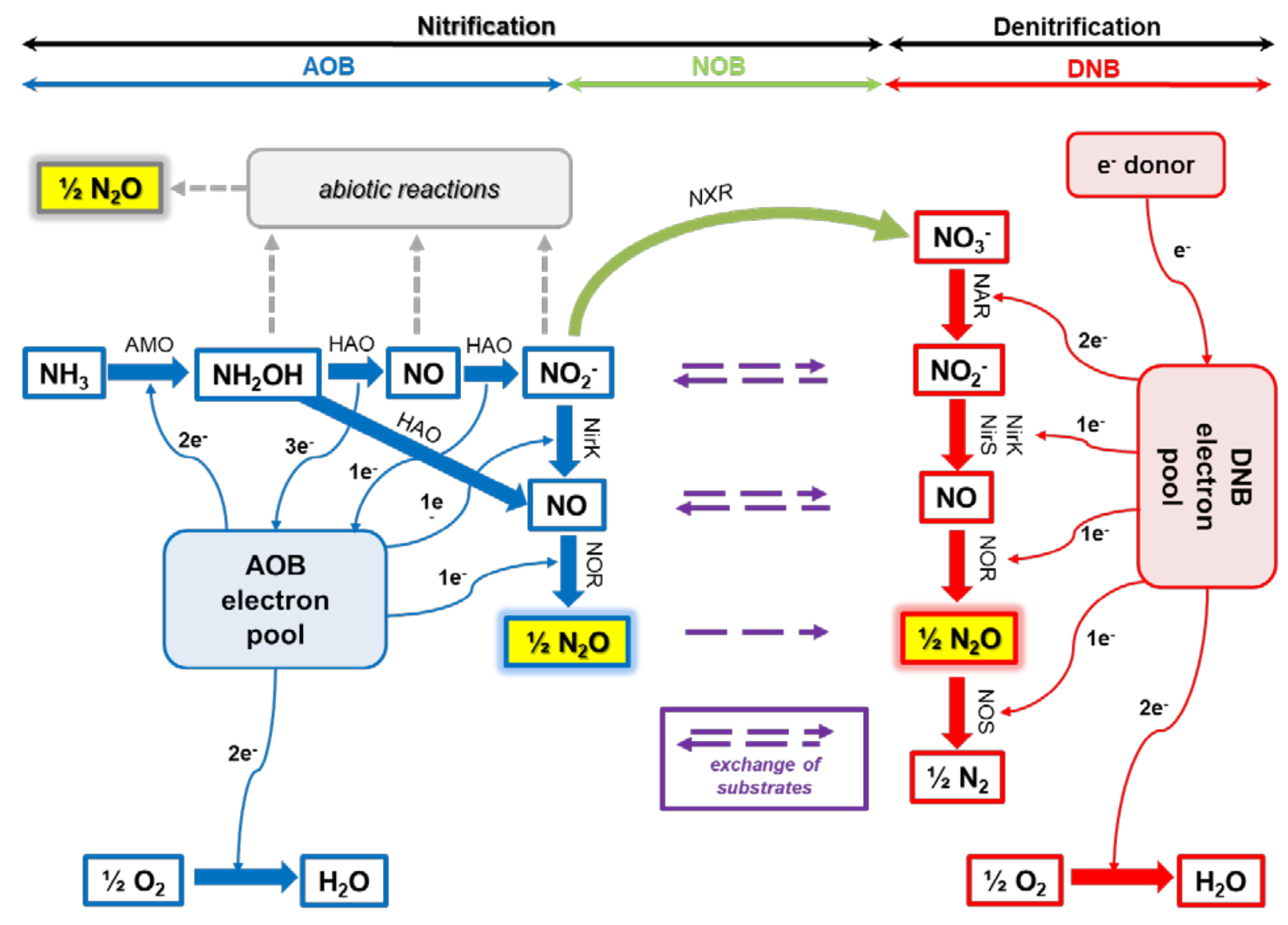

1112

1113

1114 
(B)

1117

1118

1119

1120

1121

1122

1123
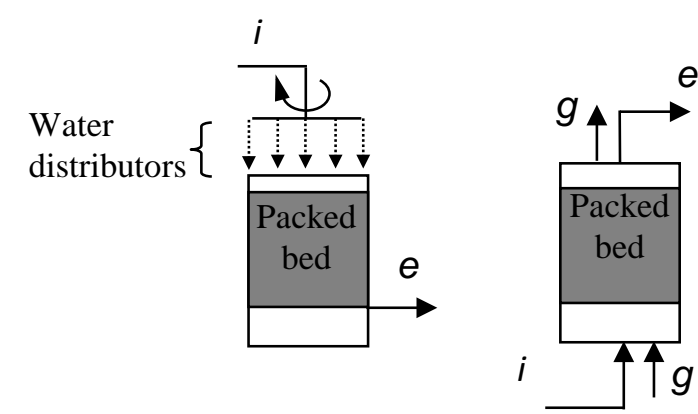

(C)

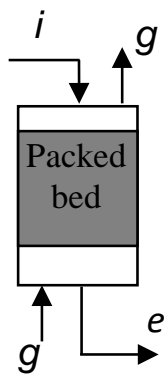

(D)

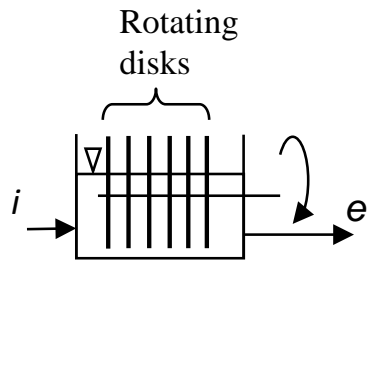

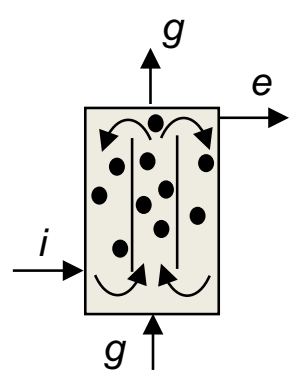

(E)

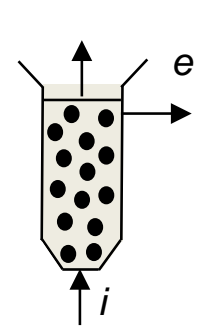

(F)

(F)

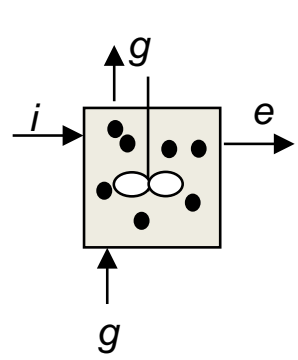

(G)

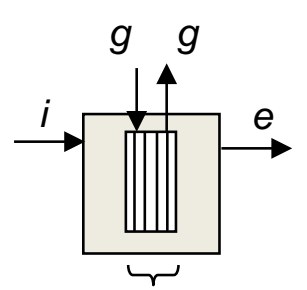

Gas-transferring membranes

(G)

(H) 
(a)

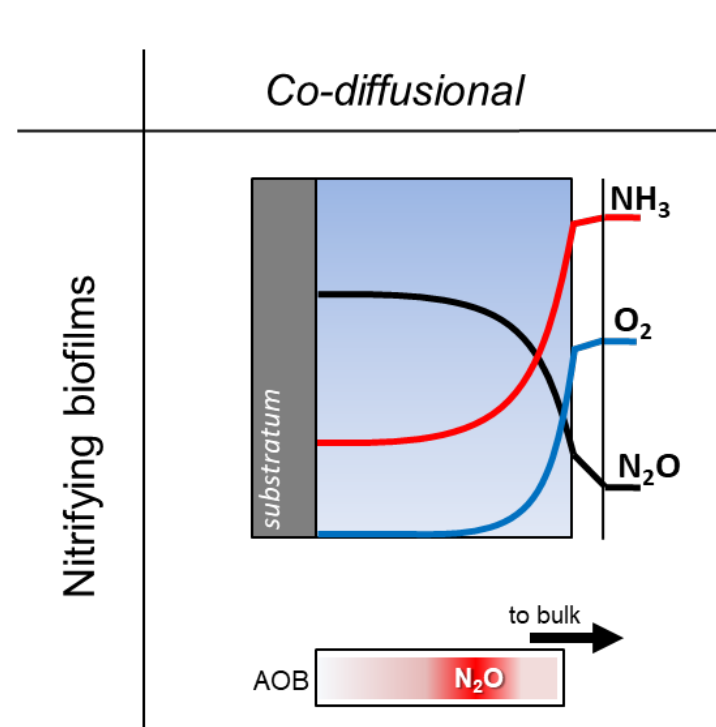

(b)

Membrane aerated

(Counter-diffusional)

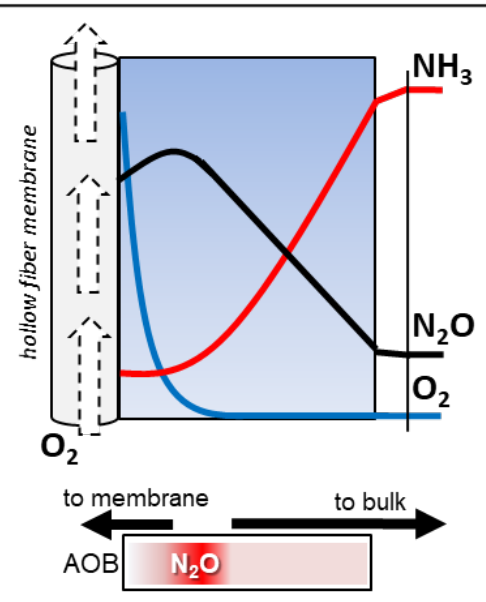

1124

1125 
(a)

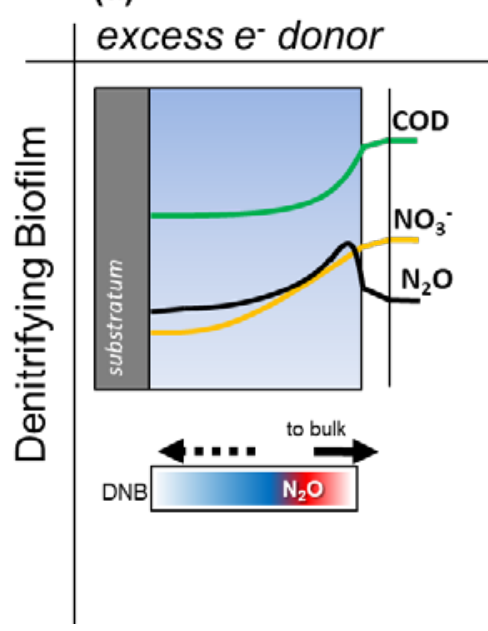

(b) excess $e^{-}$donor with $\mathrm{O}_{2} \quad$ limiting $\mathrm{e}^{-}$donor

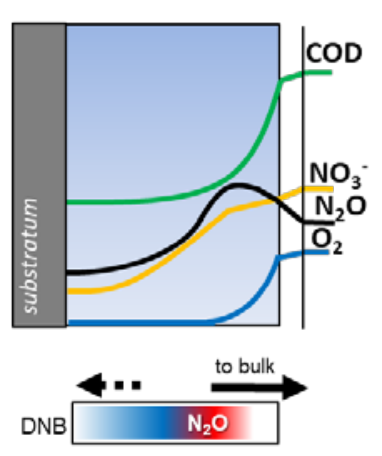

(c)

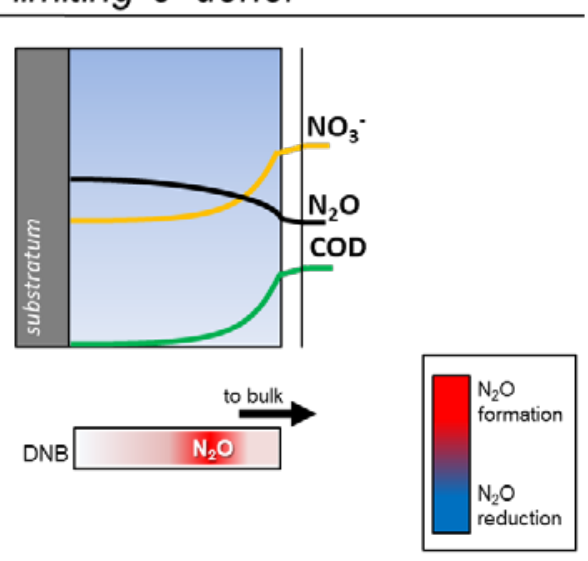

1126

1127

1128 
(a)

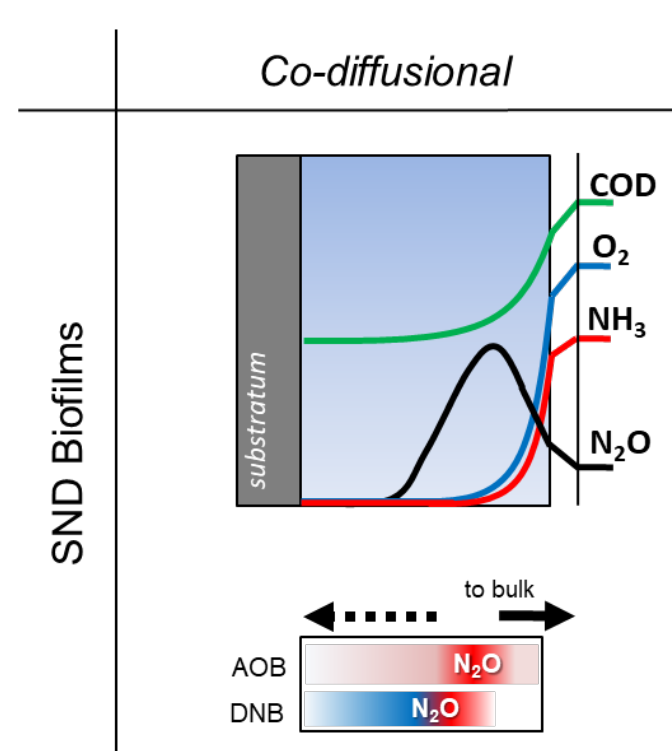

(b)

Membrane aerated (Counter-diffusional)

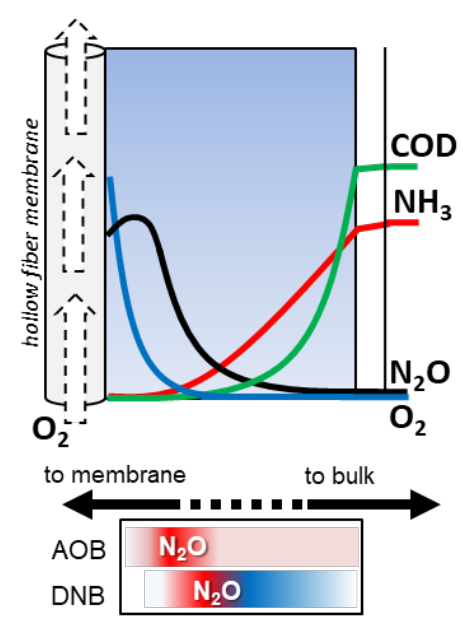

